\title{
Role of MiRNAs and it's single nucleotide polymorphism in breast cancer
}

${ }^{1}$ Debarshi Roy, ${ }^{1,3}$ Ramesh Bandla, ${ }^{2}$ Praveen Boddana, ${ }^{3}$ Rajesh Medisetty, ${ }^{* 1}$ Raghu Gogada

${ }^{1}$ Department of Biochemistry and Plant Physiology; ${ }^{2}$ Department of Plant Pathology, M.S. Swaminathan School of Agriculture (MSSSoA), Centurion University of Technology and Management (CUTM), Parlakhemundi-761211, Odisha, INDIA.

${ }^{3}$ Analytical Division, Biological E. Limited, Hyderabad, Telangana, INDIA.

*Correspondence may be addressed to email: raghu.gogada@cutm.ac.in

\begin{abstract}
MiRNAs are 20-22 nucleotide long single-stranded non-coding RNA sequences, which can regulate post transcriptional activity of mRNA by binding with it at 3'UTR region (untranslated region). Thus deregulation of miRNA expression is responsible for dysregulating mRNA function which contributes in developing various diseases as well as cancerous phenotypes. Alteration of single nucleotide in miRNA sequence is one of the reasons behind deregulation of miRNA expression. The most frequent carcinoma in current day is breast cancer which causes a high mortality among women around the world as well as India. Despite of the advancement of diagnostic tools, strategies and treatment, the cases of breast cancer is increasing every year. There are plenty of biomarkers like ER, PR, Her2, Ki-67, etc available which are frequently used in diagnosis and treatment of breast cancer. After the discovery of MiRNA in 1993 in Caenorhabiditis elegans, it is attracting all the limelight in diagnosis and treatment of different carcinomas as well as breast cancer. In this review we will discuss on involvement of different types of MiRNAs and miR SNPs in breast cancer occurrence and susceptibility in a detailed manner.
\end{abstract}

Keywords: microRNA, SNP's, breast cancer, RNA induced silencing complex. 
Introduction: Breast Cancer is one of the leading and alarming prevalent cancers and it is the second most common cancer across the globe. According to a study performed by Ferlay et al. (1) an estimated 1.67 million new breast cancer cases were diagnosed in the year of 2012, which described breast cancer as 'most frequent cancer among women'. It is also accounted as most frequent cause of cancer related mortality among women (2). The breast cancer in India scenario is also showing the similarity with global trend. According to National Cancer registry Programme cervical and breast carcinomas are two leading cancers among Indian women. Different published reports from different cancer surveys are also indicating towards rising trends of breast cancer in India $(3,4)$. Breast Cancer prevalence among Indian women is three times higher in urban areas specially metropolitan cities like Delhi, Kolkata, Chennai, Mumbai than rural parts (5). Many life style factors such as later age marriage, late pregnancy, reduced breast feeding, age at first birth, westernization of diet, physical activity patterns may play important role in the early prognosis of breast cancer (6). Beside these, genetic factors are also crucial for developing BC in women. Although researchers are trying to focus on many known genetic factors (ex: BRCA1, BRCA2, HER2, ER, PR, etc), epigenetics and gene regulations for better understanding the prognosis and treatment of BC, recent discovery of MiRNA in 1993 has become a milestone in progression of understanding the gene regulation in many diseases as well as breast cancer (7).

MicroRNA: MicroRNAs (MiRNA) are small group of non-coding RNAs which are known for regulating gene expression through a post transcriptional mechanism, including mRNA degradation and translational repression, by binding to 3' untranslated region (UTR) of target mRNA and cleaving the mRNA with the help of Ago2 RNAase of RISC complex (RNA induced silencing complex) (8). 22 nucleotide long these small RNAs are generally found in many biological fluids like semen, saliva, vaginal fluids and menstrual secretions and frequently used as diagnostic and prognostic biomarkers for various diseases including cancer $(9,10)$. Many emerging evidences have shown involvement of miRNAs in cancer classification, global repression of maturation induced cellular transformation and tumorigenesis (11).

MiRNA synthesis: MiRNAs are transcribed from the noncoding portion of the gene by RNA polymerase-II or III in the form of primary mRNA (100-120 nt long) followed by synthesis of Drosha or DGCR8 cleaved hairpin like structured precursor miRNA (70-80 nt long) (12). The hairpin portion of pre-miRNA is cleaved by a protein called Dicer after it's transportation into cytoplasm by Exportin V and a double stranded miRNA duplex with 3' overhangs in both sides is formed. (13). This MiRNA duplex binds with RiSC complex (RNA interference Silencing Complex) which consists of Slicer, Argonout, TRNC6 etc proteins and it gets unwound by 
helicase into two single-stranded miRNAs named Guide strand and passenger strand. Later RISC complex releases passenger strand and directs guide strand which is miRNA, towards target mRNA. This mature single-stranded guide strand binds with the target mRNA, exerting it's inhibitory activity either by blocking the mRNA translation or mRNA degradation.

MiRNAs and Global Diseases: Many studies have proved importance of Micro RNAs in different developmental processes metabolism, cell proliferation, apoptosis, developmental timing, and neuronal cell fate (14-18) along with other regulatory roles including neuronal gene expression (19), brain morphogenesis (20), muscle differentiation (21), and stem cell division (22). MiRNAs have pivotal role in controlling several cellular growth and differentiation processes and also altered patterns of MiRNAs in cells can induce malignancy in cells, which shows influence of MiRNAs in developing cancer (23-25). MiRNA deficiencies or excesses or changes in MiRNA functions due to single point mutations or its target or epigenetic silencing of of MiRNA transcription units have found to be linked with many diseases such as myocardial infraction, autoimmune disease, etc (26). Rapid progress in MiRNA research in past few years have opened new horizon in diagnosing and treating of many diseases (27). Here we will discuss about occurrence of few diseases due to dysregulation of MiRNA structure and expression.

Cardiovascular Diseases and cardiac failure: In spite of necessity of more research in precise mechanism involved in cardiovascular biological functions, an increasing number of studies show Micro RNAs have pivotal role in regulating mammalian cardiovascular growth, proliferation, cell differentiation and apoptosis and changes in MiRNA expression level can influence developmental process and disease states like cardiac hypertrophy and failure (28). Few studies claim that abundant expressions of miR-1, miR-16, miR-27b, miR-30d, miR-126, miR-133, miR-143, and the let-7 have been found in adult cardiac tissues (29). Generally in the heart three MiRNAs, miR-1, miR-133 and miR-208 are highly expressed (30,31) and have been found to regulate mostly heart development and myocyte differentiation, whereas deregulated expression of miR-1 and miR-133 have been found to be involved in human heart failure (32-35). In case of cardiac hypertrophy miR-23a, miR-23b, miR-24, miR-195, miR199a, and miR-214 were found upregulated and their overexpression in cardiomyocytes in vitro may be responsible behind it (36).

Inflammatory Diseases: Recent days a number of studies have investigated miRNA's role in vascular inflammation and leukocyte activation and their infiltration into the vascular wall. The study which is thought to be the first evidence of miRNA regulation demonstrated the that miR- 
126 inhibits vascular cell adhesion molecule 1 (VCAM-1) expression where VCAM-1 is necessary for mediating leukocyte adherence to endothelial cells $(37,38,39)$. Some studies have shown cytokines like TNF $\alpha$ and IFN- $\beta$ can induce miRNA-155 in macrophages, contribute to physiological granulocyte/monocyte expansion during inflammation (40). Few miRNAs such as miR-17-92 cluster, miR-150 in regulating B-cell differentiation and miR-181 in regulating haematopoietic lineage differentiation have been found in many reports (41-44). Besides this involvement of miR-424 in regulating translation of transcription factor NFI-A during monocyte or macrophage differentiation, induction of miR-146 in macrophages in by several microbial components and proinflammatory cytokines, moreover regulation of granulocyte differentiation and activation during inflammation by myeloid specific miR-223 strengthen the claim of importance of miRNA in regulation of human immune system and different inflammatory diseases (45-48).

Neurodevelopmental Disease: Near about 1000 MiRNAs should be expressed in all human brains according to high throughput sequencing experiments whether current studies suggest this number is around 550, which shows the high expression of MiRNAs in human brains (49). Changes of MiRNA expression levels in early or later brain development may be representative of biochemical signals for determining cellular fate, different cell division programming or/and apoptosis in brain (50). Therefore it can be speculated that the pathogenesis of neurodevelopmental disorders such as intellectual disability, autism, Attention Deficit Hyperactivity Disorder (ADHD) and epilepsy are linked with miRNA expression changes (51). Fragile X syndrome (FXS), a genetic disorder which was first found to be linked with miRNA pathway occurs due to interaction between FMRP (Fragile X Mental Retardation Protein, which is a product of FMR-1 gene) and Dicer-derived miRNAs. This interaction can regulate target mRNA translation by binding non coding miRNA structures within UTRs of target mRNAs in inducing the genetic Fragile X syndrome (52-64). Another neurodevelopmental syndrome is Rett syndrome which occurs due to de novo mutations in MECP2 gene which causes aberrations in the DNA methyl-CpG-binding protein, MeCP2. Postnatally cultured rat neurons have shown direct repression of MeCP2 expression by miR-132, which indicates the importance of miRNA role in regulating MeCP2 by which postnatal neuronal development and synaptic maturation are maintained $(52,65,66)$. Potential evidence of MiRNA role in Down syndrome individuals also have been found in many studies. Few bioinformatics analyses have revealed that five miRNAs; miR-99a,let-7c, miR-125b-2, miR-155 and miR-802 are encoded in chromosome 21, triplication of all or part of which is responsible for developing Down Syndrome. These all above mentioned miRNAs have been found to be overexpressed in fetal 
brain and heart tissues of DS individuals, which may be responsible for developing cognitive and cardiac defects in Down syndromic individuals $(52,67)$. According to Sethupathy P et al. miR-155 downregulates angiotensin II type 1 receptor (AGTR1) gene, associated with hypertension. The AGTR1 protein generally is also found in lower levels among DS patients than individuals without DS (68). These all findings indicates towards the importance of miRNA role in Down Syndromic individuals. Dysregulation of specific miRNA expressions has been elucidated to be linked also with Alzheimer Disease. Loss of miR-29 cluster associated with increased (beta-amyloid precursor protein-converting enzyme) BACE1/betasecretase expression in sporadic AD patients, direct interaction of miR-298 and miR-328 with 30-UTR of BACE1 transcript involved in b-amyloid production, regulation of the expression of Amyloid Precursor Protein (APP) by miR-20a family (e.g. miR-20a, miR-17-5p and miR$106 \mathrm{~b}$ ) or elevated expressions of miR-9, miR-128a and miR-125b in AD hippocampus, there are plenty of evidences of involvement of micro RNAs in AD development have been found (69-71). In case of Schizophrenia, researchers have found association between miRNA and BDNF (Brain-derived Neurotrophic Factor), which plays important role in regulating development and synaptic maintenance of a variety of neurons in the CNS including GABA and glutamatergic neurons. Few bioinformatics studies suggest that newly described miRNAs, has-mir-1 and has-mir-206 can regulate BDNF protein synthesis by interfering in BDNF mRNA translation during brain development which indicates towards importance of miRNA roles in Schizophrenic patients (72-74).

Autoimmune Diseases: Many studies have already shown some possible roles of miRNAs regulating two most significant autoimmune diseases rheumatoid arthritis (RA) and Systemic Lupus Erythematosus (SLE). Two miRNAs, miR-155 and miR-146 were found significantly overexpressed in synovial tissues and synovial fibroblasts of RA patients than healthy individuals. Later Stanczyk J et al. and Tili E et al. found significant elevated expression of both these miRNAs in synovial fibroblasts of RA individuals following TNF/ interleukin (IL)$1 \beta$ stimulation (75-77). Few studies suggest as pathogenesis of RA is linked with many viral infections such as Epstein-Barr Virus (EBV), chronic Hepatitis C Virus (HCV), HIV and Kaposi's-sarcoma associated herpes, which have the ability to encode their own miRNAs which can control viral transcripts' expressions and suppress the host immune response during infection (78-80). miR-UL112-1 expressed by the human cytomegalovirus targeting MHC class 1-related chain B and miR-K12-11 encoded by the Kaposi's-sarcoma-associated herpes virus for downregulating numerous similar cellular target mRNAs expression can be two ideal examples of it $(80,81)$. In a microarray analysis for studying miRNA expressions in Systemic 
Lupus Erythematosus seven miRNAs (miR-196a, miR-17-5p, miR-409-3p, miR-141, miR383, miR-112, and miR-184) were found downregulated and nine miRNAs (miR-189, miR-61, miR-78, miR-21, miR-142-3p, miR-342, miR-299-3p, miR- 198, and miR-298) were found upregulated compared to healthy controls (82). Still more research is necessary for confirming association of miRNA function with autoimmune diseases.

Liver Diseases: Understanding the miRNA regulation in liver physiology and different liver diseases like Viral Hepatitis, polycystic liver diseases have gained a lot of attention. As previously discussed, viral protein coding genes have ability of encoding their own miRNAs which can regulate their own protein coding genes. Hepatitis B Virus can be a good example in this case. The pre-miRNA transcribed from HBV gene can control its own gene expression $(83,84)$. Even miRNA from host cell also can regulate viral genes. Regulating the replication of HCV (Hepatitis C Virus) by miR-122 has already been shown. claim. Studies also have shown eight miRNAs (miR-1,miR-30, miR-128, miR-196, miR-296, miR-351, miR-431 and miR-448) among 30 cellular miRNAs, influenced by IFN- $\alpha / \beta$ or IFN- $\gamma$, were upregulated who have an almost perfect complementarity with HCV RNA genomes. This suggests the capability of these miRNAs in HCV replication and infection inhibition (85). According to Lee et al, 2008, miR-15a levels were decreased in livers of patients suffering from Autosomal Recessive Polycystic Kidney Disease (ARPKD), indicates that miRNA expression changes may be responsible in phenotypic changes found in cystic liver disease (86).

Other Diseases: In regulation of muscle development along with hair follicle morphogenesis, autoimmune and chronic inflammatory diseases which affect skin, involvement of miRNAs have been noticed in many studies (87-92). Having signature role of Muscle-specific miR-1, miR-133 and miR-20 in myogenesis, significant up-regulation of miRNAs-100, 103 and 107 in certain myopathies, diagnosing Facio scapula humeral muscular dystrophy (FSHD) distinguished from Duchenne muscular dystrophy (DMD) based on the level of miRNAs-381 and miRNAs-382 expressions prove the importance of miRNAs in muscular development (9395). Similarly, many studies claim involvement of a cluster of 33 miRNAs in regulation of expression of target genes required for the entry of fibroblasts into the cell cycle and proliferation. In context dermal fibroblasts are important cells in wound healing process. Another review also has outlined potential significance of involvement of miRNAs in wound angiogenesis and abnormal healing sequence in chronic wounds (96-99). These show miRNAs play important role in developing skin disease.

miRNAs in cancer: It has already been well established by many studies that overexpression or down-regulation of miRNAs which have oncogenic as well as tumor suppressor activity, 
play crucial role in human cancers (100-102). In reproductive cancers such as breast, ovary, and endometrioid adenocarcinoma along with colon and haematological cancer (ALL,AML,CLL,CML), esophagus, gastrointestinal, lung, bladder, and thyroid tumors, miRNA play crucial role. (103) (Table 2,3)

Table 1: miRNAs in human diseases (127)

\begin{tabular}{|c|c|c|c|}
\hline Disease type & miRNA & $\begin{array}{l}\text { Up/Down } \\
\text { Regulation }\end{array}$ & References \\
\hline \multicolumn{4}{|c|}{ Cardiac hypertrophy } \\
\hline & $\begin{array}{c}\operatorname{miR}-23 a, m i R-23 b, \underset{m i R}{\operatorname{miR}}-24, \operatorname{miR}-195, \operatorname{miR}-199 a, \text { and } \\
\operatorname{miR}-214\end{array}$ & Up & 74 \\
\hline \multicolumn{4}{|c|}{ Down syndrome } \\
\hline & miR-99a, let-7c, miR-125b-2, miR-155 and miR-802 & Up & 133 \\
\hline \multicolumn{4}{|l|}{ Alzheimer } \\
\hline & $\operatorname{miR}-9, \operatorname{miR}-128 \mathrm{a}, \mathrm{miR}-125 \mathrm{~b}$ & Up & 140 \\
\hline \multicolumn{4}{|c|}{ Rheunnatic arthritis } \\
\hline & $\operatorname{miR}-155, \mathrm{miR}-146$ & $\mathrm{Up}$ & 156 \\
\hline \multicolumn{4}{|c|}{ Systemic lupus erythematosus } \\
\hline & $\begin{array}{l}\operatorname{miR}-189, \operatorname{miR}-61, \operatorname{miR}-78, \operatorname{miR}-21, \operatorname{miR}-142-3 p \\
\text { miR } 342, \text { miR-299-3p, miR-198 and miR-298 }\end{array}$ & Up & \\
\hline & $\begin{array}{l}\mathrm{miR}-196 \mathrm{a}, \mathrm{miR}-17-5 \mathrm{p}, \mathrm{miR}-409-3 \mathrm{p}, \mathrm{miR}-141, \mathrm{miR}-383, \\
\text { miR-112, and miR-184 }\end{array}$ & Down & 165 \\
\hline \multicolumn{4}{|l|}{ Psoriasis } \\
\hline & $\mathrm{miR}-203$ & Up & 183 \\
\hline
\end{tabular}

Table 2: MiRNAs in reproductive cancers. (126)

\begin{tabular}{lcc}
\hline Cancer type & miRNA & $\begin{array}{c}\text { Up/Down } \\
\text { Regulation }\end{array}$ \\
\hline Breast & miR-21, miR-155, miR-23, and miR-191 & Up \\
& miR-205, miR-145, miR-10b, and miR-125b & Down \\
Ovary & miR-200a, miR-200c, and miR-141 & Up \\
& $\begin{array}{c}\text { miR-199a, miR-140, miR-145, and miR125b1 } \\
\text { Endometrioid adenocarcinoma } \\
\text { miR-205, miR155 miR 200a, 200b, 200c } \\
\text { miR-193a, 193b }\end{array}$ & Down \\
& & Down \\
\hline
\end{tabular}


Table 3: miRNAS in cancer. (126)

\begin{tabular}{|c|c|c|}
\hline $\begin{array}{l}\text { Cancer } \\
\text { type }\end{array}$ & miRNA & $\begin{array}{l}\text { Up/Down } \\
\text { Regulation }\end{array}$ \\
\hline \multicolumn{3}{|l|}{ Colon } \\
\hline & $\begin{array}{l}\text { miR-let 7g, miR-21, miR-20a, miR-17- } 19 \text { family, miR } \\
\text { 31, miR 135, miR-181b, and miR 200c } \\
\text { miR-34, miR-let7, miR 143, miR } 145, \text { miR-133b, and } \\
\text { miR-126 }\end{array}$ & $\begin{array}{c}\text { Up } \\
\text { Down }\end{array}$ \\
\hline \multicolumn{3}{|c|}{ 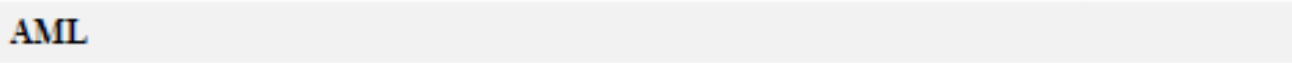 } \\
\hline & Has- miR-191, 199a, miR 155 & Up \\
\hline \multicolumn{3}{|l|}{ CML } \\
\hline & $\begin{array}{l}\operatorname{miR}-17-5 p, \operatorname{miR}-173 p, \operatorname{miR}-18 a, \operatorname{miR}-19 a, m i R-19 b-1, \\
\text { miR-20a and miR-92a-1 }\end{array}$ & Up \\
\hline \multicolumn{3}{|c|}{$e^{-3}$} \\
\hline & miR-21, miR $150, \operatorname{miR}-155$ & Up \\
\hline & $\begin{array}{c}\operatorname{miR}-15 a, \operatorname{miR} 16, \operatorname{miR}-29, \operatorname{miR} 143, \operatorname{miR}-45, \operatorname{miR}-30 \mathrm{~d}, \\
\text { miR- let 7a, miR-181a }\end{array}$ & Down \\
\hline
\end{tabular}

Recent studies have shown importance of miRNAs also in angiogenesis as let-7b, miR-16, miR-21, miR-23a, miR-29, miR-100, miR-221, and miR-222 expressions were found to be associated with endothelial cells (104-106). Role of miRNAs in vascular cells has been elucidated by miRNA regulation during pathophysiological process. Researchers have conducted studies where downregulation and overexpression of miR-130 in quiescent HUVEC and in response to foetal bovine serum were shown respectively $(107,108)$. Some research studies show induction of miR-210 expression in hypoxia, which also was reported to be overexpressed in the enhanced formation of capillary-like structures inhibited in decreased tube formation and migration (108). miR-221 and miR-222 who have anti-angiogenic effects are highly expressed in HUVEC as well as endothelial cells and reduction of endothelial Nitric Oxide Synthase's (eNOS) expression is occurred due to same reason $(109,110)$. eNOS is known for modulating endothelial cell growth, migration, vascular remodelling, and angiogenesis, which are linked with various tumour tissues including bladder, colon, pancreatic cancers, etc. $(111,112,113,114)$

Breast Cancer subtypes: On basis of gene expression profile and the phenotype the breast cancer be divided into six subtypes luminal A, luminal B, tumour enriched with human 
epidermal growth factor receptor 2 (Her2), basal-like, normal-like and claudin-low subtype (115-118).

Luminal A subtype: This is the most common subtype among all breast cancer subtypes, which accounts for $50 \%-60 \%$ of the total breast cancer cases. It is characterized by ER (Estrogen Receptor), PR (Progesterone Receptor), Bcl-2 expressions and absence of Her2 $(116,117)$.

Luminal B subtype: Luminal B subtype can be characterized by the expressions of ER,PR and absence of Her2 and can be differentiated from the Luminal A subtype based on high Ki67 staining which is an indicator of high proliferation rate (119).

Her2 Positive subtype: Almost $15-20 \%$ breast cancers are of this subtype, which is characterized by high expression of the Her2 gene and high proliferation rate. Although the survival rate of this subtype has been increased in last decade, still the prognosis remains poor. Basal-like subtype: This subtype constitutes $10-20 \%$ of all breast carcinomas and often shows poor prognosis. Among all of the three markers (ER, PR, Her2) none is expressed in Basal like subtype breast cancer cases. Instead of having controversial chemotherapeutic approaches, promising strategies are being developed for treating this type of breast cancer $(118,120)$.

Normal-like subtype: Poorly characterized this subtype constitutes 5-10\% of all breast cancers, where ER, PR and Her2 are expressed and it's clinical outcome is in between basal like and luminal-A subtype. Few researchers doubt regarding this subtype's existence as it can not be confirmed by microarray approach and it has the possibility to contaminate surrounding normal tissues.

Claudin-low subtype: Being triple negative in nature this subtype is characterized by low expression of claudin-3, 4, 7, ocludin and E-cadherin, where claudin is a tight junction protein and E-cadherin is a calcium dependent cell-cell adhesion glycoprotein. Having stem like features this breast cancer subtype constitutes $10-14 \%$ of all cancers and has a poor long term prognosis $(118,121,122)$.

miRNA expression pattern specificity in certain cancer subtype: Expression of miRNAs are specific to specific cancer subtypes. miR-21, miR-210 and miR-221, who have been correlated with worse patient disease-free and overall survival, play a crucial role in triple negative breast cancer and also have been noticed to be significantly overexpressed, whereas miR-10b, miR-145, miR-205 and miR-122a have been found significantly downregulated in these cancer types (120). Comprehensive miRNA profiling in normal basal and luminal breast epithelium cells isolated from plastic surgery showed 116 out of 664 miRNAs were expressed in normal breast epithelium, whereas among them 8 miRNAs let7c, miR-125b, miR-126, miR- 
127-3p, miR-143, miR-145, miR-146-5p and miR-199a-3p were significantly overexpressed in normal basal cells and miR-200c and miR-429 were mostly luminal. In some studies, higher expression of miR-126,miR-127, miR-143, miR-145 and miR199 and downregulation of miR200c and miR-429 were noticed in malignant myoepithelioma compared with luminal and basal-like subtypes (123). According to an artificial network analysis conducted for miRNA profiling of 29 early stage breast cancer patients for determining ER,PR and Her2 status by Lowrey et al., miR-342, miR-299, miR-217, miR-190, miR-135b, miR-218 were ER specific, miR-520 g, miR-377, miR-527-518a, miR-520f-520c were PR specific and miR-520d, miR181c, miR-302c, miR-376b and miR-30e were Her2 specific. Furthermore, highest expression of miR-342 in ER and Her2positive luminal B tumours and lowest expression of miR-520g in ER and PR-positive tumours were revealed by further analysis (124).

Classification of MiRNAs involved in breast cancer: Researchers have shown around 50\% of the human miRNA-encoding genes are present in such regions of fragile chromosomal site which are linked with cancer (125). After the first study related to miRNA measurement in serum, conducted by Lawrie et al, where miR-21 were found to be associated with relapse free survival of the patients having diffuse large B-cell lymphoma (128). Several studies have shown the use of miRNAs as potential biomarkers in different type of cancers like prostate cancer (129), lung cancer, colorectal cancer (130,131), ovarian cancer (132), renal cell carcinoma (133), squamous cell carcinoma of the tongue (134), and glioblastoma (135). The first study on miRNA dysregulation in breast cancer was reported in 2005 (136). Since then several studies have shown altered expression of miRNAs in breast carcinoma. These breast cancer related miRNAs can be subdivided into two types: oncogenic miRNAs (oncomiRs) and tumor suppressor miRNAs (tsmiRs) (137).

Oncogenic miRNA: Oncogenic miRNAs have been observed to be frequently upregulated and repress the expression of tumour suppressor gene/s, generally which remain involved in apoptosis, cell proliferation, cell migration and invasion and metastasis (138). Here we will discuss about some miRNAs or miRNA families which have already been studied and established as oncomiRs in breast cancer and their involvement in this cancer type.

miRNA-10 family: This miR family consists of two miRNAs: miR-10a and miR-10b, and as they can regulate HOX transcripts, they have crucial role in developmental process (139). Retaining within the HOX cluster of developmental regulators these miRNAs also have been reported to be involved in various cancers such as glioblastoma (140), colon cancer (141), acute myeloid leukemia (142), melanoma (143), pancreatic cancer (144) and hepatocellular carcinoma (145) including breast cancer. In case of breast carcinoma miR-10 family has been 
found to be involved both in metastasis and development. According to reports miR-10b potentially targets E-cadherin and miR-10b expression level is positively correlated with tumour size, pathological grading, clinical staging, lymph node metastasis, Her2-positivity and tumour proliferation, whereas negative correlation was found with $\mathrm{ER}+, \mathrm{PR}+$ and $\mathrm{E}$-cadherin levels $(146,147,148)$. Researchers are claiming that miR-10b may modulate breast cancer metastasis by suppressing HOXD10, which results in elevation of pro-metastatic gene, RHOC, a Rho-GTPase family member, known for regulating actin dynamics, hence cell shape and motility. E-cadherin, which has pivotal role during inhibition of Tiam1 (T lymphoma invasion and metastasis)-mediated Rac activation and controlling cell-cell adhesion and EMT is suppressed by miR-10b, hence the ability of breast cancer cells to invade and migrate is suppressed. These indicate miR-10b can be used as biomarker for advanced progression and breast cancer metastasis $(148,149)$.

miRNA-21 family: Chan et al. first reported aberrant expression of miR-21, showing significant elevation in human glioblastoma tumour tissues along with established glioblastoma cell lines compared with non-neoplastic fetal and adult brain tissues and in the same year Iorio et al. noticed elevated expression of few miRNAs (miR-125b, miR-145 and miR-155) including miR-21 in breast tumours compared with normal breast tissues $(150,151)$. Two important molecules, PDCD4 (programmed cell death 4) and maspin (mammary serine protease inhibitor), involved in invasion and metastasis in breast cancer have been identified as miR-21 targets (152). It has been observed that miR-21 expression is negatively correlated with PTEN (phosphatase and tensin homologue) expression and upregulated by transforming growth factor- $\beta$ (TGF- $\beta$ ) in breast cancer. Despite of poor prognosis, samples from 344 patients with primary breast cancer showed elevated level of miR-21 expression (associated with aggressive disease status including high tumour grade, negative hormone receptor status and ductal carcinoma), which was found to be associated with poor disease-free survival in early stage breast cancer patients $(153,154,155)$.

miRNA-17-92 cluster: Locating in such region of DNA, which is amplified in human B-cell lymphomas, this miR cluster comprises of six mature miRNAs: miR-18b, miR-19b, miR-20a, miR-92, miR-93 and miR-106 (156,157). Along with having role in lymphoma, these miRNAs are markedly overexpressed in lung cancers, especially in small-cell lung cancer (158). In case of invasive MDA-MB-231 breast cancer cells, miR-17-5p was found to be highly expressed but in MCF-7 breast cancer cells similar result was not found. Furthermore, researchers have reported that ectopic expression of this miRNA in MCF-7 breast cancer cells led to more invasiveness and migratory phenotypes by targeting HBP $1 / \beta$-catenin pathway whereas 
downregulation of miR-17-5p suppressed the migration and invasion of MDA-MB-231 breast cancer cells in vitro (159).

miRNA 155: Having an important role in suppressing apoptosis by affecting caspase 3 most important caspase involved in the execution phase of apoptosis, miR-155 is found overexpressed in many carcinomas along with breast cancer $(160,161)$. Suppressor of cytokine signalling 1 (SOCS1), RhoA and FOXO3a are identified as some gene targets for miR-155 in breast cancer $(162,163,164)$. Inverse correlation between SOCS1 and miR155 expression along with enhancement of breast cancer cell proliferation and tumour development due to ectopic expression of miR-155 in vivo establish the oncogenic effect of miR-155 (162,163). miR-155 inhibits RhoA gene expression, which regulates cell adhesion, motility and polarity. Reestablishment of the miR-155 induced phenotypes by expressing a miR-155 insensitive version of RhoA in miR-155 overexpressing cells, indicates that miR-155 downregulates the RhoA protein expression to enhance the acquisition of EMT phenotype (165). miR-155 can regulate cell survival by downregulating it's direct target FOXO3a gene in breast cancer. Studies have shown the inverse correlation between miR-155 and FOXO3a in breast cancer cell lines, suggesting that miR-155 is an essential therapeutic target in breast cancer (166). Therefore miR-155 has a essential role in breast cancer metastasis as it is implicated in the acquisition of EMT and increases potential for invasion and metastasis.

miRNA-373/520c: miR373 and 520c are two premetastatic miRNAs which were found to be involved in promoting migration and invasion in vivo and in vitro in many studies $(170,171)$. These miRNAs are also found to show migratory phenotype by inhibiting the CD44 expression, which is known as a metastatic repressor. MCF-7 cells migration, expressing miR-373 and miR-520c was reduced by ectopic overexpression of CD44 which indicates downregulation of CD44 is essential to the migration of these cells. Also upregulation of miR-373 has been noticed during reduced expression of CD44 in metastatic breast cancer $(167,168,169)$.

miRNA-375: $\mathrm{miR}-375$ has both oncogenic and tumour suppressor roles. Investigation of miR375 levels in estrogen receptor (ER $\alpha)$-positive breast cancer cell lines showed that miR-375 overexpression was associated with proliferation. On the other hand, inhibition of miR-375 expression in ER $\alpha$-positive MCF-7 breast cells resulted in reduced proliferation and ER $\alpha$ activation also has been reported. This study also suggested that RASD1 is a potential target for miR-375 and RASD1 has an important role in cell proliferation by negatively regulating ER $\alpha$ expression, hence miR-375 has an oncogenic role in breast cancer (172). In contrary tumour suppressive role of miR-375 also has been noticed. Investigation, where MCF-7 breast cells were exposed to continuous tamoxifen to understand the miRNA's role in tamoxifen 
resistance, showing invasiveness and mesenchymal characteristics of cancer cells, showed miR-375 as one of the top downregulated miRNAs in resistant. Also increased sensitivity of tamoxifen-resistant cells, and partly reversed EMT phenotype (tumour cell invasion and metastasis) by reexpression of miR-375 were reported in that study. This study also revealed metadherin (MTDH) as miR-375 target and showed inverse correlation between miR-375 and MTDH expression in primary breast cancer cell lines (173).

miRNA-221 and miRNA-222: Both of these basal-like subtype-specific miRNAs can regulate EMT and have roles in increased cell migration and invasion along with promotion of clinically aggressive basal-like breast cancer (174). Researchers have identified few targets of these miRNAs such as tricho-rhino-phalangeal syndrome type 1 protein (TRPS1), estrogen receptor alpha (ER $\alpha)$, p27/Kip1 and p57. By repressing TRPS1they can increases the EMT-promoting protein zinc finger E-box-binding homeobox 2 (ZEB2). On the other hand, overexpression of both the miRNAs in breast cancer promotes in the progression of the more aggressive basallike breast cancer while directly targeting estrogen receptor alpha $(\mathrm{ER} \alpha)$. They also repress proteins p27/Kip1 and p57, responsible for cell cycle inhibition, resulting in increased proliferation $(174,175,176)$.

Tumour Suppressor miRNA: Like oncogenic miRNAs Tumour suppressor miRNAs also have crucial role in breast cancer.

miRNA 200 family: miR-200 family consists of five miRNAs: miR-200a, miR-200b, miR200c, miR-141 and miR-429 which are generally known to suppress EMT, which is partly mediated through regulating E-cadherin transcriptional repressors ZEB1 and ZEB2 (also known as SIP1). Significant E-cadherin expression and alteration of cell morphology to an epithelial phenotype are responsible for ectopic expression of miR200 family. In this regard, miR-200c has been noticed to regulate breast cancer cell migration, stress fibre formation, migration, invasion and elongation, along with metastasis by targeting FHOD1 and PPM1F, direct regulators of the actin cytoskeleton (177-180). Downregulation of miR-200c is also have been found to be associated with drug resistance in human breast cancer (181). Also this miRNA family is involved in regulating PLCG1, BMI1, TGF- $\beta 2$, FAP-1, ZEB and Suz12 and hence acts as tumour suppressor $(179,182-190)$. As earlier discussed, miR-200 family is involved in regulating transcription factor ZEB, an activator of EMT, overexpression of this miRNA in mouse breast cancer cells is associated with macroscopic metastasis (191). Later Korpal et al. strengthened this notion in clinical aspects. More research is needed to define this miRNAs' role in breast cancer metastasis (192). 
miRNA 205: Like miR-200 family, significant downregulation has been noticed also in miR205 in cells, who have undergone EMT in response to TGF- $\beta$ and in the triple-negative primary breast cancers $(193,194)$. In many studies this miRNA expression has been reported to be restricted in basal epithelium of mammary ducts and lobules while compared with reduced or lost expression in matching tumour specimens and breast tumours while compared with the matched normal breast tissue (195). Ectopic expression of miR-205 while directly targeting Her3 and VEGF-A can inhibit invasion, proliferation and anchorage independent growth (196). In triple negative breast cancer, p53-induced miR-205 has tumour suppressive role and it's reexpression is strongly responsible for reduction of cell proliferation, cell cycle progression and clonogenic potential in vitro and inhibition of tumour growth in vivo. This miRNA also targets E2F1 and LAMC1, who have ability to regulate cell cycle progression and cell adhesion, proliferation and migration, respectively (197).

miRNA-145: miR-145 also is significantly downregulated in breast cancer like miR-205, while compared with normal breast tissue, where N-RAS and VEGF-A were post transcriptionally targeted and regulated by miR-145 leading to inhibition of tumour angiogenesis, tumour growth and invasion, also supports this claim. N-RAS and VEGF-A are required for the above mentioned phenotypes (198). Studies suggest that this miRNA may also be used as novel cancer biomarker for early cancer detection due to its early manifestation altered expression. miR-145 has shown pro-apoptotic as well as tumour suppression functions (195). According to Spizzo et al. miR-145 has tumour suppression function along with TP53 activation dependent pro apoptotic potential in breast cancer cell lines. Also this miRNA can directly interact with estrogen receptor- $\alpha$ (ER- $\alpha$ ) expression and promote apoptosis in both ER- $\alpha$ positive and wild type TP53-expressing breast cancer cells (199). A well-known oncogene cMyc, having potential of regulating cell growth and proliferation, which can inhibit tumour cell growth both in vivo and in vitro can be silenced by miR-145 (200). Inhibition of invasion property of breast cancer cells, while having no significant involvement in cell growth, shows that miR-145 also can suppress breast cancer metastasis. Silencing of metastasis gene mucin 1 (MUC1) is partially responsible for this breast tumour suppression (201). Furthermore, miR145 also has observed to suppress cell-cell adhesion protein JAM-A and fascine in breast tumour cell lines, which is responsible for drastically decreasing cell motility (202).

Let-7 family: In let-7 family there are total 10 members: let-7a, let-7b, let-7c, let-7d, let-7e, let-7f, let-7g, let-7i, miR-98 and miR-202, which are basically involved in muscle formation, cell adhesion and gene expression and development regulation (203,204). Let-7 is generally downregulated in many cancers such as lung cancer (205), gastric cancer (206), colon cancer 
(207) and Burkitt lymphoma (208), whereas in breast cancer it is lost at an early stage of disease progression (209). Yu et al. found reduced expression of let-7 family miRNAs in breast tumour initiating cells (BT-IC) and increase with differentiation. On the other hand overexpressed let7 miRNAs can reduce proliferation, mammosphere formation of BT-IC in vitro and tumour formation and metastasis in NOD/SCID mice. Let-7 miRNAs target H-RAS and HMGA2, which suggests that let-7 can regulate BT-IC stem cell-like properties by silencing multiple targets (210).

miRNA-125: Both isoforms of miR-125, miR-125a and miR-125b have been found to be significantly downregulated in breast cancer patients $(214,215)$. In a study conducted by Guo et al. decreased expression of miRNA-125 was observed where, miR-125a was inversely correlated with HUR expression (an RNA binding protein overexpressed in several different cancers) in various breast cancer cell lines. Overexpression of $125 \mathrm{a}$ was associated with decreased HUR levels, which is responsible for cell growth, and reduced cell migration and proliferation, suggests that HUR is a potential target of miR-125a for suppressing breast tumour $(210,211,212)$. miR-125a and miR-125b both were downregulated also in breast cancer cases where HER2 (human epidermal growth factor receptor 2) which is common in most of the cancers including breast cancer patients, is over expressed (212). Researchers have proposed c-Raf as target of miR-125b for exerting it's antiproliferative effect (213).

miRNA-206: miR-206 has been observed to be upregulated in estrogen receptor negative (ER) breast cancers and play a crucial role in inhibiting the expression of the estrogen receptor gene ERa (ESRl) (216). A study conducted by showed reduced expression of miR-206 in ER $\alpha$-positive human breast cancer tissues. That miR-206 was found to suppress ESR1 expression along with MCF-7 breast cancer cells' growth inhibition (217). Another study which demonstrated downregulation of miR-206 in metastatic breast cancer cells in comparison to normal parental cells, also supports the tumour suppressive role of miR-206 (218). These findings support the potential role of miR-206 in suppressing breast cancer migration.

miRNA-31: Having pleotropic effects on breast cancer metastasis, miR-31 has been observed to inhibit metastasis in multiple steps by inhibiting premetastatic genes expression. Ectopic overexpression of miR-31 in MDA-MB-231 and SUM-159 breast cancer cells in vitro and in vivo, showed encapsulated and less invasive cancer instead of larger tumours formation and increased proliferation. Also, miR-31 can reduce cell survival and secondary tumours formation ability (219). In a study where miR-31 regulation of six identified gene targets, rizzled3 ( $F z d 3)$, integrin $\alpha-5$ (ITGA5), myosin phosphatase-Rho interacting protein $(M-R I P)$, 
matrix metallopeptidase $16(M M P 16)$, radixin $(R D X)$ and $R h o A$ were investigated, showed only ITGA5, RDX, and RhoA had the ability to reverse the motility defects and impaired invasion. This suggests these three genes as important targets of miR-31 (220). These studies indicate miR-31 as inhibitor of metastasis and increased invasiveness.

miRNA-34a : p53 regulated this miRNA, which remains downregulated in several cancers, has been found in lower levels in triple negative and mesenchymal-type breast cancer cell lines when compared to the normal epithelial cell lines. This study suggests that p53 mutation may be responsible for the reduced miR-34 expression (211,221). Furthermore, study on effect of miR-34a on breast cancer development reporting downregulation of this miRNA in five different breast cancer cell lines compared to the normal epithelial cell line 184A1 and inhibition of breast cancer cell proliferation and migration through downregulation of its targets, Bcl-2 and SIRT1, strengthen the claim of miR-34a having tumour suppressive role in breast carcinoma (222).

miRNA-342: miR-342 has tumour suppressive role in tamoxifen resistant breast cancer cells. Tamoxifen resistance is a major problem in clinical applications today, where inspite of being one of the most prescribed endocrine therapies, about $30 \%-40 \%$ of patients fail adjuvant tamoxifen therapy and almost all of these patients having metastatic cancer, develop tamoxifen resistance as well. Tamoxifen is a selective estrogen receptor (ER $\alpha)$ modulator and has effects in breast cancer patients particularly where HER2 receptor tyrosine kinase overexpresses (223). Studies suggest HER2 which is a significant tamoxifen resistant factor has a splice oncogenic isoform HER $2 \Delta 16$ associated with metastatic breast cancer and resistance to endocrine therapy (224). Another study revealed contribution of miR-342 to tamoxifen resistance in several models, including cell lines that overexpress HER2 $\Delta 16$. Furthermore, miR-342 is found to be downregulated in tamoxifen resistant breast cancer cell lines along with tamoxifen refractory breast cancers (225).

Role of miRNA polymorphisms in breast cancer occurrence or susceptibility: One of the most famous and discussible genetic variations in current day is Single nucleotide polymorphism (SNP) which found almost in every 100-300 bases and plays crucial role in developing several cancers including breast cancer $(231,232)$. SNPs found in miRNA coding genes or in the miRNA binding target genes either form new miRNA or alter target mRNA function due to overexpression of the target gene, which describes miRNAs as potential biomarkers for cancer/breast cancer prognosis and clinical management. (233-236). Here role of miRSNPs in breast cancer occurrence and susceptibility will be discussed on the basis of three criteria. 
1. SNPs in target genes affecting micro RNA-mRNA interaction.

2. SNPs in miRNA Biogenesis Genes.

3. SNPs in genes that encode microRNAs.

SNPs in miR target genes affecting micro RNA-mRNA interaction: SNPs found in the 3' Untranslated region (UTR) of miRNA target gene can play an important role in altering the mRNA-miRNA interaction, which may increase the risk of cancer including breast cancer, if the target gene is oncogene or tumour suppressor gene. (237-239). There are almost 27 SNPs which have been mentioned in the following table, which play crucial role in breast cancer. (Table 4) In MDM4 family, constitutes of MDM2 and MDM4 genes, rs4245739 SNP has been found to be involved in reduced risk of breast cancer. This gene family is found in the epithelial cells that line the lumen of milk ducts in a matured breast (240). rs4245739 SNP (A>C) in 3' UTR region of MDM4 genes, which can negatively regulate $\mathrm{p} 53$, a tumour suppressor protein having vital role in cancer pathogenesis, is a target of miRNA-191 (241-243). Phe191Tyr (T>A), another novel SNP found in 3' UTR region of Spleen tyrosine kinase (SYK), has been observed to play important role in increased breast cancer risk (244-246). Spleen tyrosine kinase (SYK), is a member of the nonreceptor tyrosine kinase family and normally expressed in the breast epithelial tissue (246). Studies have shown expression of this gene family in breast tissue in addition to cell lines of breast cancer (247). According to many studies increased level of SET8 expression can inhibit cell apoptosis by p53 transcriptional activation suppression; which promotes tumour migration along with invasion by enhancing the EMT $(248,249)$. SET8 is known for catalysing the histone H4 K20 monomethylating and also non-histone proteins like p53. (250,251). Among 129 variants of SET8, rs16917496 (T>C), which is a novel SNP, has been observed to be located inside 3'-UTR region, capable of binding with miR-520, which can regulate breast cancer risk. (252,253). Palladin (PALLD) (an actin-associated protein involved in actin-rich structures colocalization) is a target gene for miR-96 and miR-182, which have controversial effect on increased risk of breast cancer and its invasion. Despite of it, rs $1071738(\mathrm{C}>\mathrm{G}) \mathrm{SNP}$, which is located in the target site of miR-96 ad miR-182, on 3' UTR region of PALLD, is found to be associated with increased risk of breast cancer. The above mentioned miRNAs' seed regions are entirely complimented to the 3'-UTR region of PALLD, hence a mismatch, seen in the presence of $\mathrm{G}$ allele can abolish the antimetastasis effect of miR182 and miR-96 in this regard (254-259). These SNPs are novel among the 27 SNPs mentioned in the table. Studies suggest C allele of rs7963551 in the 3'UTR region of RAD52 which is binding site of let-7 miRNA and AC variant allele and CC allele genotypes of same SNP have 
reduced risk of breast cancer occurrence. On the other hand, in case of women having a higher number of pregnancies, the A allele of rs7963551 showed significantly higher breast cancer risk. (261,262). In the 3'UTR region of BRCA1 gene miR-SNP rs8176318, miR-SNP rs12516 and miR-SNP rs3092995 have been identified to play crucial role in breast occurrence (260). reported rs8176318 miR-SNP for predicting breast (including TNBC) and ovarian cancer risk in a population of Irish women. According to another study homozygosity for the A alleles in miR-SNPs rs12516 and rs8176318 was significant associated with familial breast and ovarian cancer in a Thai cohort (263). On the other hand, elevated breast cancer risk was observed among in African American breast cancer patients having rs3092995, with the G allele predominant as compared to control subjects (264). miR-SNP rs1042538 in the core binding region of miR-124 in IQGAP1 (encoding IQ motif-containing GTPase-activating protein 1) can be predictive for breast cancer risk and prognosis. In Chinese population, TT genotype of this SNP is associated with lower breast cancer risk when compared to the AA genotype. Whether AA genotype has been found to be linked with higher breast cancer risk (265). Brenden and colleagues found strong association of miR-SNP rs743554 in the ITGB4 3'UTR region with specific risk of developing ER-negative breast cancers and worse overall survival when compared to those with the wildtype alleles. They also showed impairment of miR-34a binding to the ITGB4 30UTR seed region by this SNP (266). A case control study in German population, where 1223 breast cancer families and 1495 controls were compared to study the effect of rs2747648 SNP in the 3'UTR miRNA binding site of ESR1, demonstrated that the T allele variant of this miR-SNP was associated with increased breast cancer risk in premenopausal women, whereas another group of researchers reported $\mathrm{C}$ allele genotypes of this SNP in same categoric women with lower breast cancer risk. (267). AG genotype of SNP rs334348 in the 3'UTR of TGFBR1 has been reported to be prone to breast cancer where, G allele is targeted by miR-628-5p with higher efficacy than its A allele counterpart in vitro (268). On the other hand, in the same study, SNP rs 1982073 in TGFB1 was observed to exert its effect on gene expression with miR-187 altered interaction, and CC carriers of this SNP was linked to increased risk of breast cancer (268). CT and TT variants of miR-SNP rs115160714 in the 3'UTR region of Topoisomerase IIb binding protein 1 (TOPBP1) are found to be associated with higher breast cancer risk, when compared to CC genotype in Caucasian populations, TOPBP1 is hypothesized to bind with three miRNAs (miR-3138, miR-4302, and miR-1207$5 p)$ and reported to possess rs115160714 (269,270). Overexpression of Matrix Metalloproteinases (MMP9) in multiple cancers are associated with increased invasion and poorer prognosis. Researchers have reported that The C allele of the miR-SNP rs 1056628 can 
bind and affect 3'UTR region of miR-491-5p targeted MMP9 which can prevent miRNAmediated inhibition $(271,272)$. In an Iranian population this c allele has been observed to be linked with increased breast cancer (273).

Table 4: miRNAs in cancer. (126)

\begin{tabular}{|c|c|c|}
\hline Cancer type & miRNA & $\begin{array}{l}\text { Up/Down } \\
\text { Regulation }\end{array}$ \\
\hline \multicolumn{3}{|l|}{ Esophagus } \\
\hline & miR-194, miR- 192, miR-200c & Up \\
\hline & miR- 203 & Down \\
\hline \multicolumn{3}{|c|}{ Gastrointestinal } \\
\hline & miR-106b- 25 & Up \\
\hline & $\mathrm{miR}-15 \mathrm{~b}, \mathrm{miR}-16$ & Down \\
\hline \multicolumn{3}{|l|}{ Lung } \\
\hline & has-mir-21 and has-mir- 205, miR- 17-92 & Up \\
\hline & has-mir-126*, miR-let 7, hsa-let-7a-2, let-7f-1 & Down \\
\hline \multicolumn{3}{|c|}{ 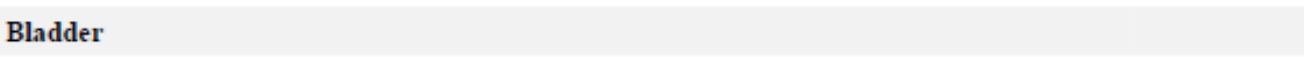 } \\
\hline & $\begin{array}{c}\operatorname{miR}-223, \operatorname{miR}-26 b, m i R-221, m i R-103-1, \operatorname{miR}-185, m i R-23 b, \\
\text { miR-203,miR } 17-5 p, m i R-23, m i R-205\end{array}$ & Up \\
\hline & miR-29c, miR-26a, miR-30c, miR-30e-5p & Down \\
\hline \multicolumn{3}{|l|}{ Thyroid tumors } \\
\hline $\mathrm{PC}$ & miR- 146 b, miR- 221, miR- 222, miR- $181 b$, miR- 155, miR- 224 & Up \\
\hline $\mathrm{AC}$ & miR-30d, miR-125b, miR-26a, miR-30a- 5p & Down \\
\hline
\end{tabular}

SNPs in miRNA Biogenesis Genes : A very recent review by Poonam Malhotra et al., 2019 described more elaborately the effect of SNPs in miRNA biogenesis genes (274). SNPs rs644236 (C > T) and rs7737174 (A > G) in DROSHA (Nuclear RNAse III), which is a key factor in the execution of the initiation step of miRNA processing was found to be linked with elevated risk of developing breast cancer in Korean post-menopausal women whereas rs2291109 (A > T) SNP in the same gene was found to be associated with increased breast cancer susceptibility (275,276). DGCR8 is an essential component of the pri-miRNA processing complex with Drosha. rs9606250 (A > T) and rs417309 (A > G), these two polymorphisms have been found in elevated breast cancer risk in Korean and Chinese breast cancer patients respectively $(276,277)$. Epigenetic state of Exportin 5, known as XPO5 is responsible for exporting pre-miRNAs from the nucleus. missense SNP rs11544382 (A > G) was observed to be significantly linked with breast cancer susceptibility when compared to 
homozygous controls, in Caucasian women. rs34324334 along with rs11544382 were found to be highly prone to develop breast cancer due to altered nucleocytoplasmic transport activity in post menopausal women (278). SNP rs1057035 (C > T), located in the 3'UTR of DICER1, a RNAIII protein in cytoplasm, having role in cleaving pre-miRNA to miRNA, has been observed to play significant role in disease-free survival, overall survival and elevation of breast cancer progression and breast cancer associated mortality (277,279). AGO2 a critical factor from in RISC (RNA interfering Silencing complex) complex, brings miRNA to the target site. Two SNPs rs11786030 (A > G) and rs2292779 (C > G), located in AGO2 were resulted in decreased free survival and poor overall survival. On the other hand SNP rs3864659 (A > C) in AGO2 was observed to have a protective role against breast cancer risk in a study conducted within Korean population. $(275,277)$.

SNPs in genes that encode microRNAs: Single Nucleotide Polymorphism in miRNA coding gene sequence possibly develops new miRNA with altered function, which can regulate target mRNA due to multiple reasons including structural changes and affecting the $\mathrm{CpG}$ island of promoters $(235,280)$. Studies suggest SNPs in microRNA may have crucial role in breast cancer occurrence (281). Around 13 SNPs have been demonstrated in (Table 5). Very recently few studies have observed more single nucleotide polymorphisms in miRNA encoding gene which were linked to breast cancer occurrence. miRNA 605, located on chromosome 10q21.1 plays a important role in the regulation of tumorigenesis and cancers (227). Arezu Kazemi, 2019 et al. conducted a study on 162 females affected by breast cancer from Iraian population to identify the correlation between rs2043556 in miR-605 and breast cancer. They performed the study using restriction fragment length polymorphism (RFLP) followed by Sanger sequencing and found rs2043556 to be associated with increased risk of breast cancer susceptibility. (226). A metanalysis study performed to correlate role of polymorphisms in miR-146a rs2910164, miR-196a rs11614913 and miR-499 rs3746444 with breast cancer risk showed rs11614913 CC genotype in miR-196a2 was linked with elevated level of breast cancer occurrence. This study is useful for early detection of breast cancer (229). Another metanalysis on these functional miRNAs' SNPs reported increased breast cancer risk with miR-499 rs3746444 in Asians and in the overall populations, while miR-196a rs11614913 was found in decreased association with breast cancer risk among Caucasians. They did not find any relationship between miR-146a rs2910164 with breast cancer susceptibility (230). On the other hand variant genotypes rs 3746444 in miR-499 were reported to be associated with significantly increased risks of breast cancer in Chinese women (228). According to researchers The G allele of miR-SNP rs895819 (A > G) of pre-miR-27a is associated with a significantly reduced risk 
of breast cancer in variant compared to controls in a German study cohort (54). Later a metaanalysis also reported the same though it showed reduced breast cancer risk in Caucasian population (55). But in another study by Feng and colleagues on Asian cohort found rs895819 SNP was linked to an elevated risk of breast cancer (56). Hence, effect of are population specific.

Table 5: (Gene Polymorphisms and their role in breast cancer susceptibility; Ref: microRNA-related single-nucleotide polymorphisms and breast cancer, Farbod Bahreini et al., 2020).

a) While the referenced articles investigated the mentioned allelic variants, the SNP database of https://www.ncbi.nlm.nih.gov shows the allelic variants as presented in parenthesis.

b) This SNP does not have any rs number as it is considered as a novel one and has not been submitted in any database.

\begin{tabular}{|c|c|c|c|c|c|c|}
\hline Gene & Role & $\begin{array}{l}\text { Single-nucleotide } \\
\text { polymorphism }\end{array}$ & $\begin{array}{l}\text { Allelic } \\
\text { variants }\end{array}$ & Related microRNA & $\begin{array}{l}\text { Breast cancer } \\
\text { association }\end{array}$ & References \\
\hline Bcl2 & Prevention of normal cell apoptosis & rs 1016860 & $C>T$ & $\operatorname{miR}-629$ & Increased risk & $\begin{array}{l}\text { Hashemi Doulabi, Ghaedi, Ranji, and Khazaei } \\
\text { Koohpar (2020) }\end{array}$ \\
\hline $\begin{array}{c}\text { Bmpr1- } \\
\text { b }\end{array}$ & Phosphorylation of SMAD protein & rs1434536 & $C>T$ & miR-125b & Increased risk & Saetrom et al. (2009) \\
\hline \multirow[t]{2}{*}{ Brca1 } & DNA repairing & rs8176318 & $\begin{array}{l}C>A \\
(G>T)^{a}\end{array}$ & $\begin{array}{l}\text { miR-1182 miR-149 miR-345 } \\
\text { miR-544 miR-639 }\end{array}$ & Increased risk & $\begin{array}{l}\text { Ahmad, Jalil, Haq, and Shah (2019); F. Yang, Chen, } \\
\text { Xu, and Guan (2016) }\end{array}$ \\
\hline & & rs 12516 & $\begin{array}{l}C>T \\
(G>A)^{a}\end{array}$ & $\begin{array}{l}\text { miR-188-5p miR-502-5p miR- } \\
557 \text { miR-623 miR-637 } \\
\quad \text { miR-639 }\end{array}$ & Increased risk & F. Yang et al. (2016) \\
\hline Brca2 & DNA repairing & rs15869 & $A>C$ & $\operatorname{miR}-548$ & Increased risk & Cao et al. (2016); Sanchez-Chaparro et al. (2020) \\
\hline $\mathrm{Cd} 44$ & & rs13347 & $C>T$ & miR-509-3p & Increased risk & L. Jiang et al. (2012) \\
\hline \multirow[t]{2}{*}{ ErbB4 } & Arresting the cell cycle & rs1836724 & $\begin{array}{l}C>T \\
(G>A)^{a}\end{array}$ & $\begin{array}{l}\text { miR-28-5p miR-708-5p } \\
\quad \text { miR-665 }\end{array}$ & Increased risk & $\begin{array}{l}\text { Bagheri, Mesrian Tanha, Mojtabavi Naeini, Ghaedi, } \\
\text { and Azadeh (2016); Zabihi et al. (2017) }\end{array}$ \\
\hline & Inducing differentiation & rs1972820 & $G>A$ & $\operatorname{miR}-3144-3 p$ & Reduced risk & Zabihi et al. (2017) \\
\hline \multirow[t]{2}{*}{ Esr1 } & $\begin{array}{l}\text { Increasing the proliferation rate in } \\
\text { breast tissue }\end{array}$ & rs1062577 & $T>A$ & miR-186 miR-3636 miR-3662 & Increased risk & Dehghan et al. (2017) \\
\hline & & rs 2747648 & $C>T$ & $\operatorname{miR}-453$ & Increased risk & Tchatchou et al. (2009) \\
\hline Gata3 & Embryonic & rs 1058240 & $G>A$ & miR-1299- miR-182- miR-95 & Increased risk & F. Yang et al. (2014) \\
\hline Hpgd & Prostaglandins metabolism & rs8752 & $\begin{array}{l}G>A \\
(C>T)^{a}\end{array}$ & miR-485-5p & Increased risk & He et al. (2014) \\
\hline $1123 r$ & Differentiation & rs10889677 & $C>A$ & $\begin{array}{l}\text { Let-7e } \\
\text { Let-7f }\end{array}$ & Increased risk & L. Wang et al. (2012) \\
\hline Iqgap1 & $\begin{array}{l}\text { Negative regulation of E-cadherin- } \\
\text { mediated cell-cell adhesion }\end{array}$ & rs 1042538 & $T>A$ & $\operatorname{miR}-124$ & Increased risk & Walch et al. (2008); Zheng et al. (2011) \\
\hline $\operatorname{ltgb} 4$ & Cell growth regulation & rs743554 & $G>A$ & miR-34a & Increased risk & Brendle et al. (2008) \\
\hline Kif14 & Cell proliferation & rs 10800708 & $A>T$ & $\begin{array}{l}\text { miR-892a miR-4252 miR-5095 } \\
\quad \text { miR-2114-3p }\end{array}$ & Increased risk & $\begin{array}{l}\text { Shasttiri, Rostamian Delavar, Baghi, Dehghani } \\
\text { Ashkezari, and Ghaedi (2019) }\end{array}$ \\
\hline MDM4 & Negative regulation of $p 53$ & rs4245739 & $A>C$ & miR-191 & Reduced risk & $\begin{array}{l}\text { Haupt, Maya, Kazaz, and Oren (1997); J. Liu et al. } \\
\text { (2013); Oliner et al. (1993) }\end{array}$ \\
\hline Mmp9 & Collagen degradation & rs1056628 & $A>C$ & miR-491-5p & Increased risk & Pirooz et al. (2018) \\
\hline
\end{tabular}


Table 6: Association of breast cancer risk with SNPs in miR target genes; Gene Polymorphisms and their role in breast cancer susceptibility (Ref: microRNA-related single-nucleotide polymorphisms and breast cancer, Farbod Bahreini et al., 2020).

\begin{tabular}{|c|c|c|c|c|c|}
\hline microRNA & Target gene & $\begin{array}{l}\text { Allelic } \\
\text { variants }\end{array}$ & SNP & $\begin{array}{l}\text { Breast cancer } \\
\text { association }\end{array}$ & References \\
\hline miR-101 & $\begin{array}{l}\text { NRF2 } \\
\text { SOX2 }\end{array}$ & $\begin{array}{l}C>G \\
C>T \\
G>C\end{array}$ & $\begin{array}{l}\text { rs7536540 } \\
\text { rs462489 } \\
\text { rs1053872 }\end{array}$ & $\begin{array}{l}\text { No effect } \\
\text { Increased risk } \\
\text { Increased risk }\end{array}$ & $\begin{array}{l}\text { J. Chen et al. (2014); J. Wang et al. (2017); Yi, Huang, Wen, } \\
\text { and Yi (2019) }\end{array}$ \\
\hline miR-145 & TGF $\beta$ R2 & $\mathrm{T}>\mathrm{C}$ & rs353291 & Increased risk & Chacon-Cortes et al. (2015); Garcia-Garcia et al. (2019) \\
\hline miR-146a & ERBB2 & $\mathrm{G}>\mathrm{C}$ & rs2910164 & Controversial & $\begin{array}{l}\text { Meshkat et al. (2016); Shen et al. (2008); Q. Sun et al. } \\
\text { (2014); Venkitaraman (2001) }\end{array}$ \\
\hline miR-196a2 & Brca1 & $\mathrm{C}>\mathrm{T}$ & rs11614913 & Increased risk & Morales et al. (2018); Yan, Gao, and Zhang (2017) \\
\hline miR-27a & $\begin{array}{l}\text { SPRY } 2 \\
\text { TMEM170B } \\
\text { BAK }\end{array}$ & $\begin{array}{l}A>G \\
(T>A, C, G)^{a}\end{array}$ & rs895819 & Reduced risk & Li, Xu, Ding, and Tang (2019); Morales et al. (2016) \\
\hline miR-34 & ERBB2 & $\mathrm{T}>\mathrm{C}$ & rs4938723 & Controversial & Bensen et al. (2013); Sanaei et al. (2016) \\
\hline miR-423 & BRMS1 & $A>C$ & rs6505162 & Controversial & Pollard et al. (2018); X. Sun, Wang, Liu, and Wang (2017) \\
\hline $\operatorname{miR}-499$ & $\begin{array}{l}\text { FOXO4 PDCD4 } \\
\text { Sox6 } \\
\text { Rod1 }\end{array}$ & $A>G$ & rs3746444 & Increased risk & $\begin{array}{l}\text { X. P. Ma, Zhang, Peng, Yu, and Jiang de (2013); Morales et al. } \\
\text { (2018); Yan et al. (2017) }\end{array}$ \\
\hline miR-520f & ERBB2 & $G>A$ & rs75598818 & Reduced risk & $\begin{array}{l}\text { Harvey et al. (2015); Keklikoglou et al. (2012); Meshkat, } \\
\text { Mesrian Tanha, Ghaedi, and Meshkat (2018); Yang, } \\
\text { Zhao, Wei, Zuo, and Zhu (2017) }\end{array}$ \\
\hline miR-559 & ERBB2 & $C>T$ & rs58450758 & Increased risk & $\begin{array}{l}\text { Bahreini, Ramezani, Shahangian, Salehi, and Mashayekhi } \\
\text { (2019); H. Chen et al. (2009); D. P. Wang et al. (2020); } \\
\text { F. Yang et al. (2019) }\end{array}$ \\
\hline miR-618 & FOXP2 & $A>C$ & rs2682818 & Increased risk & Feng, Ji, Liang, and Fan (2019); Morales et al. (2016) \\
\hline
\end{tabular}

Perspective: Since the discovery of miRNA in 1993 by Lee and colleagues, the importance of this small molecule has been growing rapidly. miRNAs have been found to be associated in various diseases including several carcinomas. Similarly in occurring breast cancer also miRNA and miRNA related SNPs have immense importance. This phenomena has opened a new horizon in cancer research as well as breast cancer study. As Breast cancer is the best 
studied cancer according to pathobiology, subtypes and treatment, the role of miRNAs are well characterized. In this review we have shown many miRNAs and their SNPs who can regulate tumour metastasis, invasion, migration along with apoptotic activity in breast carcinoma. miRNAs also have ability to regulate several pathways. More importantly, miRNAs exert their silencing function through a complex process depended on cellular content, revealing tissue or cell type-specific phenotypes. (283) Expression of miR related SNPs (SNPs in miRNA synthesising genes, miRNA target genes and miRNA encoding genes) and their effect in breast cancer are population specific. Here also we have noticed many studies which support this claim. Therefore more studies on miR SNPs in different population will help researchers to understand their role in breast cancer progression. So, more understanding in miRNA and their SNPs is required in coming days, Specially interactional networks between miRNAs and the human genome, transcriptome and proteome is very important to clearly understand. These studies will help researchers to transit the previous promising laboratory results into diagnostics and prognosis of breast cancer along with efficacious therapies in clinical practice (283). In conclusion, studies on miRNAs and miRSNPs can be bring revolution in breast cancer prognosis and treatment in near future.

\section{Reference:}

1. Ferlay J, Soerjomataram I, Ervik M. et al. (2013) Cancer incidence and mortality worldwide: IARC Cancer base No. 11 [Internet], Lyon, France: International agency for research on cancer; GLOBOCAN 2012.

2. Bombonati A, Sgroi D.C. (2011) The molecular pathology of breast cancer progression. $J$ Pathol. 223, 308-18.

3. Annual Reports 1982-2008 National Cancer Registry. New Delhi: Indian Council of Medical Research; 1985-2010. Available from: http://www.ncrpindia.org. [Last accessed on 2013 Jun 11]. 
4. Yeole BB. (2008) Trends in cancer incidence in female breast, cervix uteri, corpus uteri, and ovary in India. Asian Pac J Cancer Prev. 9(1), 119-22.

5. National cancer registry programme, Indian council of medical research. Three year report of population based cancer registries (2006-2008). Bangalore: India; 2010.

6. Moore MA, Ariyaratne Y, Badar F. et al. (2010) Cancer epidemiology in South Asia-past, present and future. Asian Pac J Cancer Prev. 11, 49-66.

7. Wightman B, Ha I, Ruvkun G. (1993) Post transcriptional regulation of the heterochronic gene lin-14 by lin-4 mediates temporal pattern formation in C. elegans. Cell 75, 855-62.

8. He L, Hannon GJ. (2004) MicroRNAs:small RNAs with a big role in gene regulation. Nat Rev Genet. 5, 522-31.

9. Yu J, Li A, Hong SM, Hruban RH, Goggins M. (2012) MicroRNA alterations of pancreatic intraepithelial neoplasias. Clin. Cancer Res. 18(4), 981-992.

10. Wang Y, Li Z, He C. et al. (2010) MicroRNAs expression signatures are associated with lineage and survival in acute leukemias. Blood Cells Mol. Dis. 44(3), 191-197.

11. Kent OA, Mendell JT. (2006) A small piece in the cancer puzzle: microRNAs as tumor suppressors and oncogenes. Oncogene 25(46), 6188-6196.

12. Rossbach M. (2010) Small non-coding RNAs as novel therapeutics. Curr Mol Med. $10,361 \mathrm{e} 368$.

13. Starega-Roslan J, Koscianska E, Kozlowski P, Krzyzosiak WJ. (2011) The role of the precursor structure in the biogenesis of microRNA. Cell Mol Life Sci. 68, 2859.

14. Mattick JS, Makunin IV. (2005) Small regulatory RNAs in mammals. Hum Mol Genet. 14(Suppl 1), R121- R132.

15. Berezikov E, Plasterk RH. (2005) Camels and zebrafish, viruses and cancer: a microRNA update. Hum Mol Genet. 14(Suppl 2), R183-R190.

16. Bartel, B. (2005) MicroRNAs directing siRNA biogenesis. Nat Struct Mol Biol. 12(7),569571.

17. Zamore PD, Haley B. (2005) Ribo-genome: the big world of small RNAs. Science 309(5740),1519- 1524.

18. Croce CM, Calin GA. (2005) miRNAs, cancer, and stem cell division. Cell 122(1),6-7

19. Klein ME, Impey S, Goodman RH. (2005) Role reversal: the regulation of neuronal gene expression by microRNAs. Curr Opin Neurobiol. 15(5), 507- 513.

20. Giraldez AJ, Cinalli RM, Glasner ME, Enright AJ, Thomson JM, Baskerville S. et al. (2005) MicroRNAs regulate brain morphogenesis in zebrafish. Science 308(5732),833-838. 
21. Naguibneva I, Ameyar-Zazoua M, Polesskaya A, Ait-Si-Ali S, Groisman R, Souidi M. et al. (2006) The microRNA miR-181 targets the homeobox protein Hox-A11 during mammalian myoblast differentiation. Nat Cell Biol. 8, 278-284.

22. Hatfield SD, Shcherbata HR, Fischer KA, Nakahara K, Carthew RW, Ruohola-Baker H. (2005) Stem cell division is regulated by the microRNA pathway. Nature 435, 974-978.

23. McManus MT. (2003) MicroRNAs and cancer. Semin Cancer Biol. 13(4), 253-258.

24. Bartel DP. (2004) MicroRNAs: genomics, biogenesis, mechanism and function. Cell 116(2), 281- 297.

25. Szymanski M, Barciszewska MZ, Erdmann VA, Barciszewski J. (2005) A new frontier for molecular medicine: Noncoding RNAs. Biochimica et Biophysica Acta 1756(1), 65-75.

26. Soifer HS, Rossi JJ, Sætrom P. (2007) MicroRNAs in disease and potential therapeutic applications. Mol Ther. 15, 2070-2079.

27. Li M, Mulle CM, Bharadwaj U, Chow KH, Yao Q, Chen C. (2009) MicroRNAs: control and loss of control in human physiology and disease. World J Surg. 33(4), 667-684.

28. Ali M. Ardekani and Mozhgan Moslemi Naeini. (2010) The Role of MicroRNAs in Human Diseases. Avicenna J Med Biotechnol. 2(4), 161-179.

29. Thum T, Catalucci D, Bauersachs J. (2008) MicroRNAs:novel regulators in cardiac development and disease. Cardiovas Res. 79, 562-570.

30. Baskerville S, Bartel DP. (2005) Microarray profiling of microRNAs reveals frequent coexpression with neighboring miRNAs and host genes. RNA 11, 241-247.

31. Lagos-Quintana M, Rauhut R, Yalcin A, Meyer J,Lendeckel W, Tuschl T. (2002) Identification of tissuespecific microRNAs from mouse. Curr Biol. 12(9), 735-739.

32. Zhao Y, Samal E, Srivastava D. (2005) Serum response factor regulates a muscle-specific microRNA that targets Hand2 during cardiogenesis. Nature 436, 214-220.

33. Chen JF, Mandel EM, Thomson JM, Wu Q, Callis TE, Hammond SM. et al. (2006) The role of microRNA-1 and microRNA-133 in skeletal muscle proliferation and differentiation. Nat Genet. 38, 228- 233.

34. Van Rooij E, Sutherland LB, Qi X, Richardson JA, Hill J, Olson EN. (2007) Control of stress-dependent cardiac growth and gene expression by a micro RNA. Science 316(5824), 575-579.

35. Zhao Y, Ransom JF, Li A, Vedantham V, von Drehle M, Muth AN. et al. (2007) Dysregulation of cardiogenesis, cardiac conduction, and cell cycle in mice lacking miRNA-12. Cell 129(2), 303-317. 
36. Thum T, Catalucci D, Bauersachs J. (2008) MicroRNAs:novel regulators in cardiac development and disease. Cardiovas Res. 79, 562-570.

37. Harris TA, Yamakuchi M, Ferlito M, Mendell JT, Lowenstein CJ. (2008) MicroRNA-126 regulates endothelial expression of vascular cell adhesion. Proc Natl Acad Sci. (USA) 105(5), 1516-1521.

38. O’Connell RM, Taganov KD, Boldin MP, Cheng G, Baltimore D. (2007) MicroRNA-155 is induced during the macrophage inflammatory response. Proc Natl Acad Sci. (USA) 104(5), 1604-1609.

39. Tili E, Michaille JJ, Cimino A, Costinean S, Dumitru CD, Adair B. et al. (2007) Modulation of miR-155 and miR-125b levels following lipopolysaccharide/TNF-alpha stimulation and their possible roles in regulating the response to endotoxin shock. J Immunol. 179(8), 50825089 .

40. O’Connell RM, Rao DS, Chaudhuri AA, Boldin MP, Taganov KD, Nicoll J. et al. (2008) Sustained expression of microRNA-155 in hematopoietic stem cells causes a myeloproliferative disorder. J Exp Med. 205(3), 585-594.

41. Chen CZ, Li L, Lodish HF, Bartel DP. (2004) MicroRNAs modulate hematopoietic lineage differentiation. Science 303(5654), 83-86.

42. Ventura A, Young AG, Winslow MM, Lintault L, Meissner A, Erkeland SJ. et al. (2008) Targeted deletion reveals essential and overlapping functions of the miR-17 through 92 family of miRNA clusters. Cell 132, 875-886.

43. Xiao C, Calado DP, Galler G, Thai TH, Patterson HC, Wang J. et al. (2007) MiR-150 controls B cell differentiation by targeting the transcription factor c- Myb. Cell 131(1), 146159.

44. Zhou B, Wang S, Mayr C, Bartel DP, Lodish HF. (2007) miR-150, a microRNA expressed in mature B and T cells, blocks early B cell development when expressed prematurely. Proc Natl Acad Sci. (USA) 104, 7080-7085.

45. Rosa A, Ballarino M, Sorrentino A, Sthandier O, De Angelis FG, Marchioni M. et al. (2007) The interplay between the master transcription factor PU.1 and miR-424 regulates human monocyte/macrophage differentiation. Proc Natl Acad Sci. (USA) 104 (50), 19849-19854.

46. Taganov KD, Boldin MP, Chang KJ, Baltimore D. (2006) NF-kappaB-dependent induction of microRNA miR-146, an inhibitor targeted to signaling proteins of innate immune responses. Proc Natl Acad Sci. (USA) 103(33), 12481-12486.

47. Urbich C, Kuehbacher A, Dimmeler S. (2008) Role of microRNAs in vascular diseases, inflammation and angiogenesis. Cardiovasc Res. 79(4), 581-588. 
48. Johnnidis JB, Harris MH, Wheeler RT, Stehling-Sun S, Lam MH, Kirak O. et al. (2008) Regulation of progenitor cell proliferation and granulocyte function by microRNA-223. Nature 451, 1125-1129.

49. Berezikov E, Thuemmler F, van Laake LW, Kondova I, Bontrop R, Cuppen E. et al. (2006) Diversity of microRNAs in human and chimpanzee brain. Nat Genet. 38, 1375-1377.

50. Singh SK. (2007) miRNAs: from neurogeneration to neurodegeneration. Pharmacogenomics 8(8), 971-978.

51. Ehninger D, Li W, Fox K, Stryker MP, Silva AJ. (2008) Reversing neurodevelopmental disorders in adults. Neuron 60(6), 950-960.

52. Chang S, Wen S, Chen D, Jin P. (2009) Small regulatory RNAs in neurodevelopmental disorders. Hum Mol Genet. 18, R18-R26.

53. Caudy AA, Myers M, Hannon GJ, Hammond SM. (2002) Fragile X-related protein and VIG associate with the RNA interference machinery. Genes Dev. 16, 2491-2496.

54. Ishizuka A, Siomi MC, Siomi H. (2002) A Drosophila fragile X protein interacts with components of RNAi and ribosomal proteins. Genes Dev. 16, 2497-2508.

55. Jin P, Zarnescu DC, Ceman S, Nakamoto M, Mowrey J, Jongens TA. et al. (2004) Biochemical and genetic interaction between the fragile $\mathrm{X}$ mental retardation protein and the microRNA pathway. Nat Neurosci. 7, 113-117.

56. Ashley CT Jr, Wilkinson KD, Reines D, Warren ST. (1993) FMR1 protein: conserved RNP family domains and selective RNA binding. Science 262, 563-566.

57. Feng Y, Absher D, Eberhart DE, Brown V, Malter HE, Warren ST. (1997) FMRP associates with polyribosomes as an mRNP, and the I304N mutation of severe fragile $\mathrm{X}$ syndrome abolishes this association. Mol Cell 1(1), 109-118.

58. Laggerbauer B, Ostareck D, Keidel EM, Ostareck-Lederer A, Fischer U. (2001) Evidence that fragile $\mathrm{X}$ mental retardation protein is a negative regulator of translation. Hum Mol Genet. $10,329-338$.

59. Li Z, Zhang Y, Ku L, Wilkinson KD, Warren ST, Feng Y. (2001) The fragile X mental retardation protein inhibits translation via interacting with mRNA. Nucl Acids Res. 29(11), 2276-2283.

60. Feng Y, Gutekunst CA, Eberhart DE, Yi H, Warren ST, Hersch SM. (1997) Fragile X mental retardation protein: nucleocytoplasmic shuttling and association with somatodendritic ribosomes. J Neurosci. 17(5), 1539-1547. 
61. Schaeffer C, Bardoni B, Mandel JL, Ehresmann B, Ehresmann C, Moine H. (2001) The fragile $\mathrm{X}$ mental retardation protein binds specifically to its mRNA via a purine quartet motif. EMBO J. 20, 4803-4813.

62. Darnell JC, Fraser CE, Mostovetsky O, Stefani G, Jones TA, Eddy SR. et al. (2005) Kissing complex RNAs mediate interaction between the fragile-X mental retardation protein $\mathrm{KH} 2$ domain and brain polyribosomes. Genes Dev. 19, 903-918.

63. Darnell JC, Jensen KB, Jin P, Brown V, Warren ST, Darnell RB. (2001) Fragile X mental retardation protein targets G quartet mRNAs important for neuronal function. Cell 107(4), 489499.

64. Stefani G, Fraser CE, Darnell JC, Darnell RB. (2004) Fragile X mental retardation protein is associated with translating polyribosomes in neuronal cells. J Neurosci 24(33):7272-7276.

65. Nan X, Campoy FJ, Bird A. (1997) MeCP2 is a transcriptional repressor with abundant binding sites in genomic chromatin. Cell 88(4), 471-481.

66. Klein ME, Lioy DT, Ma L, Impey S, Mandel G, Goodman RH. (2007) Homeostatic regulation of MeCP2 expression by a CREB-induced microRNA. Nat Neurosci. 10, 15131514.

67. Kuhn DE, Nuovo GJ, Martin MM, Malana GE, Pleister AP, Jiang J. et al. (2008) Human chromosome 21-derived miRNAs are overexpressed in down syndrome brains and hearts. Biochem Biophys Res Commun. 370(3), 473-477.

68. Sethupathy P, Borel C, Gagnebin M, Grant GR, Deutsch S, Elton TS. et al. (2007) Human microRNA-155 on chromosome 21 differentially interacts with its polymorphic target in the AGTR1 30 untranslated region: a mechanism for functional single nucleotide polymorphisms related to phenotypes. Am J Hum Genet. 81(2), 405-413.

69. Hebert SS, Horre K, Nicolai L, Papadopoulou AS, Mandemakers W, Silahtaroglu AN. et al. (2008) Loss of microRNA cluster miR-29a/b-1 in sporadic Alzheimer's disease correlates with increased BACE1/ beta-secretase expression. Proc Natl Acad Sci. (USA) 105(17), 64156420.

70. Boissonneault V, Plante I, Rivest, Provost P. (2009) Micro RNA-298 and microRNA-328 regulate expression of mouse beta-amyloid precursor protein-converting enzyme 1. J Biol Chem. 284, 1971-1981.

71. Johnson R, Zuccato C, Belyaev ND, Guest DJ, Cattaneo E, Buckley NJ. (2008) A microRNA-based gene dysregulation pathway in Huntington's disease. Neurobiol Dis. 29(3), $438-445$. 
72. Egan MF, Weinberger DR, Lu B. (2003) Schizophrenia, III: brain-derived neurotropic factor and genetic risk. Am J Psychiatry 160, 1242.

73. Ashe PC, Berry MD, Boulton AA. (2001) Schizophrenia, a neurodegenerative disorder with neurodevelopmental antecedents. Prog Neuropsychopharmacol Biol Psychiatry 25(4), 691-707.

74. Lewis BP, Shih IH, Jones-Rhoades MW, Bartel DP, Burge CB. Prediction of mammalian micro RNA targets. Cell 115(7), 787-798.

75. Nakasa T, Shigeru Miyaki S, Okubo A, Hashimoto M, Nishida K, Ochi M. et al. (2008) Expression of micro RNA-146 in rheumatoid arthritis synovial tissue. Arthritis Rheum 58(5), 1284-1292.

76. Stanczyk J, Pedrioli DML, Brentano F, Pernaute OS, Kolling C, Gay RE. (2008) Altered expression of MicroRNA in synovial fibroblasts and synovial tissue in rheumatoid arthritis. Arthritis Rheum 58(4), 1001-1009.

77. Tili E, Michaille JJ, Costinean S, Croce CM. (2008) Micro RNAs, the immune system and rheumatic disease. Nat Clin Pract Rheumatol. 4, 534-541.

78. Leirisalo-Repo M. (2005) Early arthritis and infection. Curr Opin Rheumatol. 17(4), 433439.

79. Callan MF. (2004) Epstein-Barr virus, arthritis, and the development of lymphoma in arthritis patients. Curr Opin Rheumatol. 16(4), 399-405.

80. Stern-Ginossar N, Elefant N, Zimmermann A, Wolf DG, Saleh N, Biton M. et al. (2007) Host immune system gene targeting by a viral miRNA. Science 317(5836), 376-381.

81. Gottwein E, Mukherjee N, Sachse C, Frenzel C, Majoros WH, Chi JTA. et al. (2007) A viral microRNA functions as an orthologue of cellular miR-155. Nature 450, 1096-1099.

82. Dai Y, Huang YS, Tang M, Lv TY, Hu CX, Tan YH. et al. (2007) Microarray analysis of microRNA expression in peripheral blood cells of systemic lupus erythematosus patients. Lupus 16(12), 939-946.

83. Berkhout B, Jeang KT. (2007) RISCy business: Micro RNAs, pathogenesis, and viruses. J Biol Chem. 282, 26641-26645.

84. Jin WB, Wu FL, Kong D, Guo AG. (2007) HBV-encoded microRNA candidate and its target. Comput Biol Chem. 31(2), 124-126.

85. Chen XM. (2009) MicroRNA signatures in liver diseases. World J Gastroenterol 15(14), 1665-1672.

86. Chu AS, Friedman JR. (2008) A role for microRNA in cystic liver and kidney diseases. $J$ Clin Invest. 118(11), 3585-3587. 
87. Ali M. Ardekani and Mozhgan Moslemi Naeini. (2010) The Role of MicroRNAs in Human Diseases. Avicenna J Med Biotechnol 2(4), 161-179.

88. Zavadil J, Narasimhan M, Blumenberg M, Schneider RJ. (2007) Transforming growth factor-beta and micro RNA: mRNA regulatory networks in epithelial plasticity. Cells Tissues Organs 185(1-3), 157-161.

89. Gu J, Iyer VR. (2006) PI3K signaling and miRNA expression during the response of quiescent human fibroblasts to distinct proliferative stimuli. Genome Biol. 7, R42.

90. Shilo S, Roy S, Khanna S, Sen CK. (2007) MicroRNA in cutaneous wound healing: a new paradigm. DNA Cell Biol. 26(4), 227-37.

91. Sonkoly E, Wei T, Janson PCJ, Saaf A, Lundeberg L, Linder MT. et al. (2007) MicroRNAs: novel regulators involved in the pathogenesis of psoriasis. PLOS ONE 2(7), e610.

92 . Yi R, O’Carroll D, Pasolli HA, Zhang Z, Dietrich FS, Tarakhovsky A. et al. (2006) Morphogenesis in skin is governed by discrete sets of differentially expressed microRNAs. Nat Genet. 38, 356-362.

93. McCarthy JJ, Esser KA. (2007) MicroRNA-1 and micro RNA-133a expression are decreased during skeletal muscle hypertrophy. J Appl Physiol. 102(1), 306-313.

94. Eisenberg I, Eran A, Nishino I, Moggio M, Lamperti C, Amato AA. et al. (2007) Distinctive patterns of microRNA expression in primary muscular disorders. Proc Natl Acad Sci. (USA) 104(43), 17016-17021.

95. Eisenberg I, Alexander MS, Kunkel LM. (2009) miRNAs in normal and diseased skeletal muscle. Cell Mol Med. 13(1), 2-11.

96. Gu J, Iyer VR. (2006) PI3K signaling and miRNA expression during the response of quiescent human fibroblasts to distinct proliferative stimuli. Genome Biol. 7, R42.

97. Shilo S, Roy S, Khanna S, Sen CK. (2007) MicroRNA in cutaneous wound healing: a new paradigm. DNA Cell Biol. 26(4), 227-37.

98. Krasna M, Domanović D, Tomsic A, Svajger U, Jeras M. (2007) Platelet gel stimulates proliferation of human dermal fibroblasts in vitro. Acta Dermatoven Alp Panonica Adriat. 16(3), 105-110.

99. Bostjancic E, Glavac D. (2008) Importance of microRNAs in skin morphogenesis and diseases. Acta Dermatoven Alp Panonica Adriat 17(3), 95-102.

100. Moslemi Naeini M, Ardekani AM. (2009) Noncoding RNAs and Cancer. Avicenna J Med Biotech. 1(2), 55-70.

101. Zhang B, Pan X, Cobb GP, Anderson TA. (2007) Micro RNAs as oncogenes and tumor suppressors. Dev Biol. 302(1), 1-12. 
102. He L, He X, Lim LP, de Stanchina E, Xuan Z, Liang Y. et al. (2007) A microRNA component of the p53 tumor suppressor network. Nature 447, 1130-1134.

103. Moslemi Naeini M, Ardekani AM. (2009) Noncoding RNAs and Cancer. Avicenna J Med Biotech. 1(2), 55-70.

104. Suarez Y, Fernandez-Hernando C, Pober JS, Sessa WC. (2007) Dicer dependent microRNAs regulate gene expression and functions in human endothelial cells. Circ Res. 100, 1164-1173.

105. Kuehbacher A, Urbich C, Zeiher AM, Dimmeler S. (2007) Role of dicer and drosha for endothelial microRNA expression and angiogenesis. Circ Res. 101, 59-68.

106. Poliseno L, Tuccoli A, Mariani L, Evangelista M, Citti L, Woods K. et al. (2006) MicroRNAs modulate the angiogenic properties of HUVECs. Blood 108(9), 3068-3071.

107. Chen Y, Gorski DH. (2008) Regulation of angiogenesis through a microRNA (miR-130a) that downregulates antiangiogenic homeobox genes GAX and HOXA5. Blood 111(3), 12171226.

108. Fasanaro P, D’Alessandra Y, Di Stefano V, Melchionna R, Romani S, Pompilio G. et al. (2008) MicroRNA-210 modulates endothelial cell response to hypoxia and inhibits the receptor tyrosine-kinase ligand Ephrin-A3. J Biol Chem. 283, 15878-15883.

109. Suarez Y, Fernandez-Hernando C, Pober JS, Sessa WC. (2007) Dicer dependent microRNAs regulate gene expression and functions in human endothelial cells. Circ Res. 100, 1164-1173.

110. Poliseno L, Tuccoli A, Mariani L, Evangelista M, Citti L, Woods K. et al. (2006) MicroRNAs modulate the angiogenic properties of HUVECs. Blood 108(9), 3068-3071.

111. Ziche M, Morbidelli L, Masini E, Amerini S, Granger HJ, Maggi CA. et al. (1994) Nitric oxide mediates angiogenesis in vivo and endothelial cell growth and migration in vitro promoted by substance P. J Clin Invest. 94(5), 2036-2044.

112. Murohara T, Witzenbichler B, Spyridopoulos I, Asahara T, Ding B, Sullivan A. et al. (1999) Role of endothelial nitric oxide synthase in endothelial cell migration. Arterioscler Thromb Vasc Biol. 19, 1156-1161.

113. Rudic RD, Shesely EG, Maeda N, Smithies O, Segal SS, Sessa WC. (1998) Direct evidence for the importance of endothelium-derived nitric oxide in vascular remodeling. J Clin Invest. 101(4), 731-736.

114. Murohara T, Asahara T, Silver M, Bauters C, Masuda H, Kalka C. et al. (1998) Nitric oxide synthase modulates angiogenesis in response to tissue ischemia. J Clin Invest. 101(11), 2567-2578. 
115. Sorlie T, Tibshirani R, Parker J, Hastie T, Marron JS, Nobel A. et al. (2003) Repeated observation of breast tumor subtypes in independent gene expression data sets. Proc Natl Acad Sci. (U S A) 100, 8418-23.

116. Sørlie T, Perou CM, Tibshirani R, Aas T, Geisler S, Johnsen H. et al. (2001) Gene expression patterns of breast carcinomas distinguish tumor subclasses with clinical implications. Proc Natl Acad Sci. (U S A) 98, 10869-74.

117. Perou CM, Sørlie T, Eisen MB, van de Rijn M, Jeffrey SS, Rees CA. et al. (2001) Molecular portraits of human breast tumours. Nature X. 406, 747-52.

118. Eroles P, Bosch A, Pérez-Fidalgo JA, Lluch A. (2012) Molecular biology in breast cancer: intrinsic subtypes and signaling pathways. Cancer Treat Rev. 38:698-707.

119. Cheang MC, Chia SK, Voduc D, Gao D, Leung S, Snider J. et al. (2009) Ki67 index, HER2 status, and prognosis of patients with luminal B breast cancer. J Natl Cancer Inst. 101, 736-50.

120. Radojicic J, Zaravinos A, Vrekoussis T, Kafousi M, Spandidos DA, Stathopoulos EN. (2011) MicroRNA expression analysis in triple-negative (ER, PR and Her2/neu) breast cancer. Cell Cycle 10, 507-17.

121. Weigelt B, Mackay A, A'hern R, Natrajan R, Tan DS, Dowsett M. et al. (2010) Breast cancer molecular profiling with single sample predictors: a retrospective analysis. Lancet Oncol. 11, 339-49;

122. Prat A, Parker JS, Karginova O, Fan C, Livasy C, Herschkowitz JI. et al. (2010) Phenotypic and molecular characterization of the claudin-low intrinsic subtype of breast cancer. Breast Cancer Res 12, R68.

123. Bockmeyer CL, Christgen M, Müller M, Fischer S, Ahrens P, Länger F. et al. (2011) MicroRNA profiles of healthy basal and luminal mammary epithelial cells are distinct and reflected in different breast cancer subtypes. Breast Cancer Res Treat. 130, 735-45.

124. Lowery AJ, Miller N, Devaney A, McNeill RE, Davoren PA, Lemetre C. et al. (2009) MicroRNA signatures predict oestrogen receptor, progesterone receptor and HER2/neu receptor status in breast cancer. Breast Cancer Res. 11, R27.

125. Melo, S.A.; Esteller, M. (2011) Dysregulation of microRNAs in cancer: Playing with fire. FEBS Lett. 585, 2087-2099.

126. Moslemi Naeini M, Ardekani AM. (2009) Noncoding RNAs and Cancer. Avicenna J Med Biotech. 1(2), 55-70.

127. Ali M. Ardekani and Mozhgan Moslemi Naein. (2010) The Role of MicroRNAs in Human Diseases. Avicenna J Med Biotech. 2(4), 161-179. 
128. Lawrie CH, Gal S, Dunlop HM. et al. (2008) Detection of elevated levels of tumourassociated microRNAs in serum of patients with diffuse large B-cell lymphoma. $\mathrm{Br} J$ Haematol. 141(5), 672e675.

129. Mitchell PS, Parkin RK, Kroh EM. et al. (2008) Circulating microRNAs as stable bloodbased markers for cancer detection. Proc Natl Acad Sci. (U S A) 105(30), 10513e10518.

130. Chen X, Ba Y, Ma L. et al. (2008) Characterization of microRNAs in serum: a novel class of biomarkers for diagnosis of cancer and other diseases. Cell Res. 18(10), 997e1006.

131. Ng EK, Chong WW, Jin H. et al. (2009) Differential expression of microRNAs in plasma of patients with colorectal cancer: a potential marker for colorectal cancer screening. Gut. 58(10), $1375 \mathrm{e} 1381$.

132. Resnick KE, Alder H, Hagan JP, Richardson DL, Croce CM, Cohn DE. (2009) The detection of differentially expressed microRNAs from the serum of ovarian cancer patients using a novel realtime PCR platform. Gynecol Oncol. 112(1), 55e59.

133. Feng G, Li G, Gentil-Perret A, Tostain J, Genin C. (2008) Elevated serum-circulating RNA in patients with conventional renal cell cancer. Anticancer Res. 28(1A), 321e326.

134. Wong TS, Liu XB, Wong BY, Ng RW, Yuen AP, Wei WI. (2008) Mature miR-184 as potential oncogenic microRNA of squamous cell carcinoma of tongue. Clin Cancer Res. 14(9), $2588 \mathrm{e} 2592$.

135. Skog J, Würdinger T, van Rijn S, et al. Glioblastoma microvesicles transport RNA and proteins that promote tumour growth and provide diagnostic biomarkers. (2008) Nat Cell Biol. 10(12), $1470 \mathrm{e} 1476$.

136. Iorio, M.V.; Ferracin, M.; Liu, C.-G.; Veronese, A.; Spizzo, R.; Sabbioni, S.; Croce, C.M. (2005) MicroRNA gene expression deregulation in human breast cancer. Cancer Res. 65, 7065-7070.

137. Hui-Yi Loh, Brendan P. Norman, Kok-Song Lai, Nik Mohd Afizan Nik Abd. Rahman, Noorjahan Banu Mohamed Alitheen and Mohd Azuraidi Osman. (2019) The Regulatory Role of MicroRNAs in Breast Cancer. Int. J. Mol. Sci. 20, 4940.

138. Zhang B, Pan X, Cobb GP, Anderson TA. (2007) microRNAs as oncogenes and tumor suppressors. Dev Biol. 302, 1-12.

139. Lund AH. miR-10 in development and cancer. (2010) Cell Death Differ. 17, 209-14.

140. Gaur A, Jewell DA, Liang Y, Ridzon D, Moore JH, Chen C. et al. (2007) Characterization of microRNA expression levels and their biological correlates in human cancer cell lines. Cancer Res. 67, 2456-68; 
141. Volinia S, Calin GA, Liu CG, Ambs S, Cimmino A, Petrocca F. et al. (2006) A microRNA expression signature of human solid tumors defines cancer gene targets. Proc Natl Acad Sci. (U S A) 103, 2257-61.

142. Jongen-Lavrencic M, Sun SM, Dijkstra MK, Valk PJ, Löwenberg B. (2008 ) MicroRNA expression profiling in relation to the genetic heterogeneity of acute myeloid leukemia. Blood $111,5078-85$.

143. Zhang L, Huang J, Yang N, Greshock J, Megraw MS, Giannakakis A. et al. (2006) microRNAs exhibit high frequency genomic alterations in human cancer. Proc Natl Acad Sci. (U S A) 103, 9136-41.

144. Bloomston M, Frankel WL, Petrocca F, Volinia S, Alder H, Hagan JP. et al. (2007) MicroRNA expression patterns to differentiate pancreatic adenocarcinoma from normal pancreas and chronic pancreatitis. JAMA 297, 1901-8.

145. Varnholt H, Drebber U, Schulze F, Wedemeyer I, Schirmacher P, Dienes HP. et al. (2008) MicroRNA gene expression profile of hepatitis $\mathrm{C}$ virus-associated hepatocellular carcinoma. Hepatology 47, 1223-32.

146. Ma L, Teruya-Feldstein J, Weinberg RA. (2007) Tumour invasion and metastasis initiated by microRNA-10b in breast cancer. Nature 449, 682-8.

147. Moriarty CH, Pursell B, Mercurio AM. (2010) miR-10b targets Tiam1: implications for Rac activation and carcinoma migration. J Biol Chem. 285, 20541-6.

148. Liu Y, Zhao J, Zhang PY, Zhang Y, Sun SY, Yu SY. et al. (2012) MicroRNA-10b targets E-cadherin and modulates breast cancer metastasis. Med Sci Monit. 18, BR299-308.

149. Minard ME, Ellis LM, Gallick GE. (2006) Tiam1 regulates cell adhesion, migration and apoptosis in colon tumor cells. Clin Exp Metastasis 23, 301-13.

150. Chan JA, Krichevsky AM, Kosik KS. (2005) MicroRNA-21 is an antiapoptotic factor in human glioblastoma cells. Cancer Res. 65, 6029-33.

151. Iorio MV, Ferracin M, Liu CG, Veronese A, Spizzo R, Sabbioni S. et al. (2005) MicroRNA gene expression deregulation in human breast cancer. Cancer Res. 65, 7065-70.

152. Zhu S, Wu H, Wu F, Nie D, Sheng S, Mo YY. (2008) MicroRNA-21 targets tumour suppressor genes in invasion and metastasis. Cell Res. 18, 350-9.

153. Huang GL, Zhang XH, Guo GL, Huang KT, Yang KY, Shen X. et al. (2009) Clinical significance of miR-21 expression in breast cancer: SYBR-Green I-based real-time RT-PCR study of invasive ductal carcinoma. Oncol Rep. 21, 673-9. 
154. Yan LX, Huang XF, Shao Q, Huang MY, Deng L, Wu QL. et al. (2008) MicroRNA miR-21 overexpression in human breast cancer is associated with advanced clinical stage, lymph node metastasis and patient poor prognosis. RNA 14, 2348-60.

155. Qian B, Katsaros D, Lu L, Preti M, Durando A, Arisio R. et al. (2009) High miR-21 expression in breast cancer associated with poor disease-free survival in early stage disease and high TGF-beta1. Breast Cancer Res Treat. 117, 131-40.

156. He L, Thomson JM, Hemann M T, Hernando-Monge E, Mu D, Goodson S. et al. (2005) A microRNA polycistron as a potential human oncogene. Nature 435, 828-33.

157. Fassina A, Marino F, Siri M, Zambello R, Ventura L, Fassan M. et al. (2012) The miR17-92 microRNA cluster: a novel diagnostic tool in large B-cell malignancies. LabInvest. 92 , 1574-82.

158. Hayashita Y, Osada H, Tatematsu Y, Yamada H, Yanagisawa K, Tomida S. et al. (2005) A polycistronic microRNA cluster, miR-17-92, is overexpressed in human lung cancers and enhances cell proliferation. Cancer Res. 65, 9628-32.

159. Li H, Bian C, Liao L, Li J, Zhao RC(2011) miR-17-5p promotes human breast cancer cell migration and invasion through suppression of HBP1. Breast Cancer Res Treat. 126:565-75. 160. Volinia, S.; Calin, G.A.; Liu, C.G.; Ambs, S.; Cimmino, A.; Petrocca, F.; Visone, R.; Iorio, M.; Roldo, C.; Ferracin, M. et al. (2006) A microRNA expression signature of human solid tumors defines cancer gene targets. Proc. Natl. Acad. Sci. (USA) 103, 2257-2261.

161. Ovcharenko, D.; Kelnar, K.; Johnson, C.; Leng, N.; Brown, D. (2007) Genome-scale microRNA and small interfering RNA screens identify small RNA modulators of TRAILinduced apoptosis pathway. Cancer Res. 67, 10782-10788.

162. Jiang, S.; Zhang, H.W.; Lu, M.H.; He, X.H.; Li, Y.; Gu, H.; Liu, M.F.; Wang, E.D. (2010) MicroRNA-155 functions as an OncomiR in breast cancer by targeting the suppressor of cytokine signalling 1 gene. Cancer Res. 70, 3119-3127.

163. Zhang, M.; Zhang, Q.; Liu, F.; Yin, L.; Yu, B.; Wu, J. (2011) MicroRNA-155 may affect allograft survival by regulating the expression of suppressor of cytokine signalling 1 . Med. Hypotheses. 77, 682-684.

164. Kong, W.; He, L.; Coppola, M.; Guo, J.; Esposito, N.N.; Coppola, D.; Cheng, J.Q. (2010) MicroRNA-155 regulates cell survival, growth, and chemo sensitivity by targeting FOXO3a in breast cancer. J. Biol. Chem. 285, 17869-17879.

165. Corcoran, C.; Friel, A.M.; Duffy, M.J.; Crown, J.; O’Driscoll, L. (2011) Intracellular and extracellular microRNAs in breast cancer. Clin. Chem. 57, 18-32. 
166. Kong, W.; He, L.; Coppola, M.; Guo, J.; Esposito, N.N.; Coppola, D.; Cheng, J.Q. (2010) MicroRNA-155 regulates cell survival, growth, and chemo sensitivity by targeting FOXO3a in breast cancer. J. Biol. Chem. 285, 17869-17879.

167. Negrini, M.; Calin, G.A. (2008) Breast cancer metastasis: A microRNA story. Breast Cancer Res. 10, 203.

168. Yang, K.; Handorean, A.M.; Iczkowski, K.A. (2009) MicroRNAs 373 and 520c are downregulated in prostate cancer, suppress CD44 translation and enhance invasion of prostate cancer cells in vitro. Int. J. Clin. Exp. Pathol. 2, 361-369.

169. Huang, Q.; Gumireddy, K.; Schrier, M.; le Sage, C.; Nagel, R.; Nair, S.; Egan, D.A.; Li, A.; Huang, G.; Klein-Szanto, A.J. et al. (2008) The microRNAs miR-373 and miR-520c promote tumour invasion and metastasis. Nat. Cell Biol. 10, 202-210.

170. Kato, M.; Paranjape, T.; Muller, R.U.; Nallur, S.; Gillespie, E.; Keane, K.; EsquelaKerscher, A.; Weidhaas, J.B.; Slack, F.J. (2009) The mir-34 microRNA is required for the DNA damage response in vivo in C. elegans and in vitro in human breast cancer cells. Oncogene 28, 2419-2424.

171. Keklikoglou, I.; Koerner, C.; Schmidt, C.; Zhang, J.D.; Heckmann, D.; Shavinskaya, A.; Allgayer, H.; Guckel, B.; Fehm, T.; Schneeweiss, A. et al. (2012) MicroRNA-520/373 family functions as a tumor suppressor in estrogen receptor negative breast cancer by targeting NF$\kappa \mathrm{B}$ and TGF- $\beta$ signaling pathways. Oncogene $31,4150-4163$.

172. De Souza Rocha, S.P.; Breiling, A.; Gupta, N.; Malekpour, M.; Youns, M.; Omranipour, R.; Malekpour, F.; Volinia, S.; Croce, C.M.; Najmabadi, H.; et al. (2010) Epigenetically deregulated microRNA-375 is involved in a positive feedback loop with estrogen receptor alpha in breast cancer cells. Cancer Res. 70, 9175-9184.

173. Ward, A.; Balwierz, A.; Zhang, J.D.; Kublbeck, M.; Pawitan, Y.; Hielscher, T.; Wiemann, S.; Sahin, O. (2012) Reexpression of microRNA-375 reverses both tamoxifen resistance and accompanying EMT-like properties in breast cancer. Oncogene.

174. Stinson, S.; Lackner, M.R.; Adai, A.T.; Yu, N.; Kim, H.J.; O’Brien, C.; Spoerke, J.; Jhunjhunwala, S.; Boyd, Z.; Januario, T. et al. (2011) TRPS1 targeting by miR-221/222 promotes the epithelial-to-mesenchymal transition in breast cancer. Sci. Signal. 4, ra41. 175. Zhao, J.J.; Lin, J.; Yang, H.; Kong, W.; He, L.; Ma, X.; Coppola, D.; Cheng, J.Q. (2008) MicroRNA-221/222 negatively regulates estrogen receptor alpha and is associated with tamoxifen resistance in breast cancer. J. Biol. Chem. 283, 31079-31086.

176. Miller, T.E.; Ghoshal, K.; Ramaswamy, B.; Roy, S.; Datta, J.; Shapiro, C.L.; Jacob, S.; 
Majumder, S. (2008) MicroRNA-221/222 confers tamoxifen resistance in breast cancer by targeting p27Kip1. J. Biol. Chem. 283, 29897-29903.

177.Park SM, Gaur AB, Lengyel E, Peter ME. (2008) The miR- 200 family determines the epithelial phenotype of cancer cells by targeting the E-cadherin repressors ZEB1 and ZEB2. Genes Dev 22, 894-907.

178. Korpal M, Lee ES, Hu G, Kang Y. (2008) The miR-200 family inhibits epithelialmesenchymal transition and cancer cell migration by direct targeting of E-cadherin transcriptional repressors ZEB1 and ZEB2. J Biol Chem. 283, 14910-4.

179. Gregory PA, Bert AG, Paterson EL, Barry SC, Tsykin A, Farshid G. et al. (2008) The miR-200 family and miR-205 regulate epithelial to mesenchymal transition by targeting ZEB1 and SIP1. Nat Cell Biol. 10, 593-601.

180. Jurmeister S, Baumann M, Balwierz A, Keklikoglou I, Ward A, Uhlmann S. et al. (2011) MicroRNA-200c Represses Migration and Invasion of Breast Cancer

Cells by Targeting Actin-Regulatory Proteins FHOD1 and PPM1F. Mol Cell Biol. 32, 633-51. 181. Chen J, Tian W, Cai H, He H, Deng Y. (2011) Downregulation of microRNA-200c is associated with drug resistance in human breast cancer. Med Oncol. 29, 2527-34.

182. Iliopoulos D, Lindahl-Allen M, Polytarchou C, Hirsch HA, Tsichlis PN, Struhl K. (2010) Loss of miR-200 inhibition of Suz12 leads to polycomb-mediated repression required for the formation and maintenance of cancer stem cells. Mol Cell 39, 761-72.

183. Uhlmann S, Zhang JD, Schwäger A, Mannsperger H, Riazalhosseini Y, Burmester S. et al. (2010) miR-200bc/429 cluster targets PLCgamma1 and differentially regulates proliferation and EGF-driven invasion than miR-200a/141 in breast cancer. Oncogene 29, 4297-306;

184. Schickel R, Park SM, Murmann AE, Peter ME. (2010) miR-200c regulates induction of apoptosis through CD95 by targeting FAP-1. Mol Cell 38, 908-15.

185. Park SM, Gaur AB, Lengyel E, Peter ME. (2008) The miR-200 family determines the epithelial phenotype of cancer cells by targeting the E-cadherin repressors ZEB1 and ZEB2. Genes Dev. 22, 894-907;

186. Li S, Wang Q, Wang Y, Chen X, Wang Z. (2009) PLCgamma1 and Rac1 coregulate EGFinduced cytoskeleton remodeling and cell migration. Mol Endocrinol 23:901-13.

187. Iliopoulos D, Polytarchou C, Hatziapostolou M, Kottakis F, Maroulakou IG, Struhl K. et al. (2009) MicroRNAs differentially regulated by Akt isoforms control EMTand stem cell renewal in cancer cells. Sci Signal 2, ra62. 
188. Gibbons DL, Lin W, Creighton CJ, Rizvi ZH, Gregory PA, Goodall GJ, et al. (2009) Contextual extracellular cues promote tumor cell EMT and metastasis by regulating miR-200 family expression. Genes Dev. 23, 2140-51.

189. Burk U, Schubert J, Wellner U, Schmalhofer O, Vincan E, Spaderna S. et al. (2008) A reciprocal repression between ZEB1 and members of the miR-200 family promotes EMT and invasion in cancer cells. EMBO Rep 9, 582-9.

190. Bracken CP, Gregory PA, Kolesnikoff N, Bert AG, Wang J, Shannon MF. et al. (2008) A double-negative feedback loop between ZEB1-SIP1 and the microRNA-20 family regulates epithelial-mesenchymal transition.Cancer Res. 68, 7846-54.

191. Dykxhoorn DM, Wu Y, Xie H, Yu F, Lal A, Petrocca F. et al. (2009) miR-200 enhances mouse breast cancer cell colonization to form distant metastases. PLoS One 4, e7181.

192. Korpal M, Ell BJ, Buffa FM, Ibrahim T, Blanco MA, Celià-Terrassa T. et al. (2011) Direct targeting of Sec23a by miR-200s influences cancer cell secretome and promotes metastatic colonization. Nat Med. 17, 1101-8.

193. Gregory PA, Bert AG, Paterson EL, Barry SC, Tsykin A, Farshid G. et al. (2008) The miR-200 family and miR-205 regulate epithelial to mesenchymal transition by targeting ZEB1 and SIP1. Nat Cell Biol. 10, 593-601.

194. Jelena R, Apostolos Z, Thomas V, Maria K, Demetrios AS, Efstathios NS. (2011) MicroRNA expression analysis in triple-negative (ER, PR and Her2/neu) breast cancer. Cell Cycle 10, 10-2.

195. Sempere LF, Christensen M, Silahtaroglu A, Bak M, Heath CV, Schwartz G. et al. (2007) Altered MicroRNA expression confined to specific epithelial cell subpopulations in breast cancer. Cancer Res. 67, 11612-20.

196. Bhaumik D, Scott GK, Schokrpur S, Patil CK, Campisi J, Benz CC. (2008) Expression of microRNA-146 suppresses NF-kappaB activity with reduction of metastatic potential in breast cancer cells. Oncogene 27, 5643-7.

197. Piovan C, Palmieri D, Di Leva G, Braccioli L, Casalini P, Nuovo G. et al. (2012) Oncosuppressive role of p53-induced miR-205 in triple negative breast cancer. Mol Oncol. 6, 458-72.

198. Zou C, Xu Q, Mao F, Li D, Bian C, Liu LZ. et al. (2012) MiR-145 inhibits tumor angiogenesis and growth by N-RAS and VEGF. Cell Cycle 11, 2137-45.

199. Spizzo R, Nicoloso MS, Lupini L, Lu Y, Fogarty J, Rossi S, et al. (2010) miR-145 participates with TP53 in a death-promoting regulatory loop and targets estrogen receptoralpha in human breast cancer cells. Cell Death Differ. 17, 246-54. 
200. Sachdeva M, Zhu S, Wu F, Wu H, Walia V, Kumar S. et al. (2009) p53 represses c-Myc through induction of the tumor suppressor miR-145. Proc Natl Acad Sci. (U S A) 106, 320712.

201. Sachdeva M, Mo YY. (2010) MicroRNA-145 suppresses cell invasion and metastasis by directly targeting mucin 1 . Cancer Res. 70, 378-87.

202. Götte M, Mohr C, Koo CY, Stock C, Vaske AK, Viola M. et al. (2010) miR-145dependent targeting of junctional adhesion molecule A and modulation of fascin expression are associated with reduced breast cancer cell motility and invasiveness. Oncogene 29, 656980 .

203. Reinhart BJ, Slack FJ, Basson M, Pasquinelli AE, Bettinger JC, Rougvie AE. et al. (2000) The 21-nucleotide let-7 RNA regulates developmental timing in Caenorhabditis elegans. Nature 403, 901-6.

204. Wang X, Cao L, Wang Y, Wang X, Liu N, You Y. (2012) Regulation of let-7 and its target oncogenes. Oncol Lett. 3, 955-60.

205. Takamizawa J, Konishi H, Yanagisawa K, Tomida S, Osada H, Endoh H. et al. (2004) Reduced expression of the let-7 microRNAs in human lung cancers in association with shortened postoperative survival. Cancer Res. 64, 3753-6.

206. Zhang HH, Wang XJ, Li GX, Yang E, Yang NM. (2007) Detection of let-7a microRNA by real-time PCR in gastric carcinoma. World J Gastroenterol 13, 2883-8.

207. Akao Y, Nakagawa Y, Naoe T. (2006) let-7 microRNA functions as a potential growth suppressor in human colon cancer cells. Biol Pharm Bull. 29, 903-6.

208. Sampson VB, Rong NH, Han J, Yang Q, Aris V, Soteropoulos P. et al. (2007) MicroRNA let-7a down-regulates MYC and reverts MYC-induced growth in

Burkitt lymphoma cells. Cancer Res. 67, 9762-70.

209. Sempere LF, Christensen M, Silahtaroglu A, Bak M, Heath CV, Schwartz G. et al. (2007) Altered MicroRNA expression confined to specific epithelial cell subpopulations in breast cancer. Cancer Res. 67, 11612-20.

210. Yu F, Yao H, Zhu P, Zhang X, Pan Q, Gong C. et al. (2007) let-7 regulates self-renewal and tumorigenicity of breast cancer cells. Cell 131, 1109-23.

210. Guo, X.; Wu, Y.; Hartley, R.S. (2009) MicroRNA-125a represses cell growth by targeting HuR in breast cancer. RNA Biol. 6, 575-583.

211. Gaur, A.; Jewell, D.A.; Liang, Y.; Ridzon, D.; Moore, J.H.; Chen, C.; Ambros, V.R.; Israel, M.A. (2007) Characterization of microRNA expression levels and their biological correlates in human cancer cell lines. Cancer Res. 67, 2456-2468. 
211. Iorio, M.V.; Ferracin, M.; Liu, C.G.; Veronese, A.; Spizzo, R.; Sabbioni, S.; Magri, E.; Pedriali, M.; Fabbri, M.; Campiglio, M. et al. (2005) MicroRNA gene expression deregulation in human breast cancer. Cancer Res. 65, 7065-7070.

212. Mattie, M.D.; Benz, C.C.; Bowers, J.; Sensinger, K.; Wong, L.; Scott, G.K.; Fedele, V.; Ginzinger, D.; Getts, R.; Haqq, C. (2006) Optimized high-throughput microRNA expression profiling provides novel biomarker assessment of clinical prostate and breast cancer biopsies. Mol. Cancer 5, 24.

213. Hofmann, M.H.; Heinrich, J.; Radziwill, G.; Moelling, K. (2009) A short hairpin DNA analogous to miR-125b inhibits C-Raf expression, proliferation, and survival of breast cancer cells. Mol. Cancer Res. 7, 1635-1644.

214. Shi, X.B.; Xue, L.; Yang, J.; Ma, A.H.; Zhao, J.; Xu, M.; Tepper, C.G.; Evans, C.P.; Kung, H.J.; vere White, R.W. (2007) An androgen-regulated miRNA suppresses Bak1 expression and induces androgen-independent growth of prostate cancer cells. Proc. Natl. Acad. Sci. (U S A) 104, 19983-19988.

215. Zhang, Y.; Gao, J.S.; Tang, X.; Tucker, L.D.; Quesenberry, P.; Rigoutsos, I.; Ramratnam, B. (2009) MicroRNA 125a and its regulation of the p53 tumor suppressor gene. FEBS Lett. 583, 3725-3730.

216. Adams, B.D.; Furneaux, H.; White, B.A. (2007) The micro-ribonucleic acid (miRNA) miR-206 targets the human estrogen receptor-alpha (ERalpha) and represses ERalpha messenger RNA and protein expression in breast cancer cell lines. Mol. Endocrinol. 21, 11321147.

217. Chen, X.; Yan, Q.; Li, S.; Zhou, L.; Yang, H.; Yang, Y.; Liu, X.; Wan, X. (2012) Expression of the tumor suppressor miR-206 is associated with cellular proliferative inhibition and impairs invasion in ERalpha-positive endometrioid adenocarcinoma. Cancer Lett. 314, 4153.

218. Tavazoie, S.F.; Alarcon, C.; Oskarsson, T.; Padua, D.; Wang, Q.; Bos, P.D.; Gerald, W.L.;Massague, J. (2008) Endogenous human microRNAs that suppress breast cancer metastasis. Nature 451, 147-152.

219. Valastyan, S.; Reinhardt, F.; Benaich, N.; Calogrias, D.; Szasz, A.M.; Wang, Z.C.; Brock, J.E.; Richardson, A.L.; Weinberg, R.A. (2009) A pleiotropically acting microRNA, miR-31, inhibits breast cancer metastasis. Cell 137, 1032-1046.

220. Valastyan, S.; Weinberg, R.A. (2010) miR-31: A crucial overseer of tumor metastasis and other emerging roles. Cell Cycle 9, 2124-2129. 
221. Kato, M.; Paranjape, T.; Muller, R.U.; Nallur, S.; Gillespie, E.; Keane, K.; EsquelaKerscher, A.;Weidhaas, J.B.; Slack, F.J. (2009) The mir-34 microRNA is required for the DNA damage response in vivo in C. elegans and in vitro in human breast cancer cells. Oncogene 28, 2419-2424.

222. Li, L.; Yuan, L.; Luo, J.; Gao, J.; Guo, J.; Xie, X. (2012) MiR-34a inhibits proliferation and migration of breast cancer through down-regulation of Bcl-2 and SIRT1. Clin. Exp. Med. in press.

223. Early Breast Cancer Trialists' Collaborative Group (EBCTCG). (2005) Effects of chemotherapy and hormonal therapy for early breast cancer on recurrence and 15-year survival: an overview of the randomised trials. Lancet 365, 1687-1717.

224. Cittelly, D.M.; Das, P.M.; Salvo, V.A.; Fonseca, J.P.; Burow, M.E.; Jones, F.E. (2010) Oncogenic HER2 $\triangle 16$ suppresses miR-15a/16 and deregulates BCL-2 to promote endocrine resistance of breast tumors. Carcinogenesis 31, 2049-2057.

225. Cittelly, D.M.; Das, P.M.; Spoelstra, N.S.; Edgerton, S.M.; Richer, J.K.; Thor, A.D.; Jones, F.E. (2010) Downregulation of miR-342 is associated with tamoxifen resistant breast tumors. Mol. Cancer 9, 317.

226. Arezu Kazemi and Sadeq Vallian, (2020) Significant Association of miR-605 rs2043556 with Susceptibility to Breast Cancer. MicroRNA Vol. 9, No. 2

227. Zhang MW, Jin MJ, Yu YX. et al. (2020) Associations of lifestyle-related factors, HSAmiR-149 and HSA-miR-605 gene polymorphisms with gastrointestinal cancer risk. Mol Carcinog 51, (Suppl. 1):E21-31.

228. Hu Z, Liang J, Wang Z, Tian T, Zhou X. et al. (2009) Common genetic variants in premicroRNAs were associated with increased risk of breast cancer in Chinese women. Hum Mutat 30: 79-84.

229. Ping-Yu Wang, Zong-Hua Gao, Zhong-Hua Jiang, Xin-Xin Li, Bao-Fa Jiang, Shu-Yang Xie. (2013) The Associations of Single Nucleotide Polymorphisms in miR-146a, miR-196a and miR-499 with Breast Cancer susceptibility. microRNAs and Breast Cancer Susceptibility Volume 8, Issue 9, e70656.

230. Hong Zhang, Yafei Zhang, Wanjun Yan, Wen Wang, Xixi Zhao, Xingcong Ma, Xiaoyan Gao, Shuqun Zhang. (2017) Association between three functional microRNA polymorphisms (miR-499 rs3746444, miR-196a rs11614913 and miR-146a rs2910164) and breast cancer risk: a meta-analysis. Oncotarget 8(1), 393-407. 
231. Abd El-Fattah, A. A., Sadik, N. A. H., Shaker, O. G., \& Mohamed Kamal, A. (2018) Single nucleotide polymorphism in SMAD7 and CHI3L1 and colorectal cancer risk. Mediators of Inflammation 9853192.

232. Iqbal, M. U. N., Yaqoob, T., Ali, S. A., \& Khan, T. A. (2019) A functional polymorphism (rs6265, G>A) of brain-derived neurotrophic factor gene and breast cancer: An association study. Breast Cancer 13, 1178223419844977.

233. Campayo, M., Navarro, A., Vinolas, N., Tejero, R., Munoz, C., Diaz, T., ...Monzo, M. (2011). A dual role for KRT81: A miR-SNP associated with recurrence in non-small-cell lung cancer and a novel marker of squamous cell lung carcinoma. PLoS One 6(7), e22509.

234. Pelletier, C., \& Weidhaas, J. B. (2010) MicroRNA binding site polymorphisms as biomarkers of cancer risk. Expert Review of Molecular Diagnostics 10(6), 817-829.

235. Sun, G., Yan, J., Noltner, K., Feng, J., Li, H., Sarkis, D. A., ... Rossi, J. J. (2009) SNPs in human miRNA genes affect biogenesis and function. RNA 15(9), 1640-1651.

236. Salzman, D. W., \& Weidhaas, J. B. (2013) SNPing cancer in the bud: MicroRNA and microRNA-target site polymorphisms as diagnostic and prognostic biomarkers in cancer. Pharmacology and Therapeutics 137(1), 55-63.

237. He, N., Zheng, H., Li, P., Zhao, Y., Zhang, W., Song, F., \& Chen, K. (2014) miR-485-5p binding site SNP rs8752 in HPGD gene is associated with breast cancer risk. PLoS One 9(7), e102093.

238. Manikandan, M., \& Munirajan, A. K. (2014) Single nucleotide polymorphisms in microRNA binding sites of oncogenes: Implications in cancer and pharmacogenomics. OMICS 18(2), 142-154.

239. Zhou, K., Liu, M., \& Cao, Y. (2017) New insight into microRNA functions in cancer: Oncogene-microRNA-tumor suppressor gene network. Frontiers in Molecular Biosciences 4, 46.

240. Burgess, A., Chia, K. M., Haupt, S., Thomas, D., Haupt, Y., \& Lim, E. (2016) Clinical overview of MDM2/X-targeted therapies. Frontiers in Oncology 6, 7.

241. Haupt, Y., Maya, R., Kazaz, A., \& Oren, M. (1997) Mdm2 promotes the rapid degradation of p53. Nature 387(6630), 296-299.

242. Liu, J., Tang, X., Li, M., Lu, C., Shi, J., Zhou, L., ... Yang, M. (2013) Functional MDM4 rs4245739 genetic variant, alone and in combination with P53 Arg72Pro polymorphism, contributes to breast cancer susceptibility. Breast Cancer Research and Treatment 140(1), $151-157$. 
243. Oliner, J. D., Pietenpol, J. A., Thiagalingam, S., Gyuris, J., Kinzler, K. W., \& Vogelstein, B. (1993) Oncoprotein MDM2 conceals the activation domain of tumour suppressor p53. Nature 362(6423), 857-860.

244. Faryal, R., Ishfaq, M., Hayat, T., Mahjabeen, I., \& Kayani, M. A. (2016) Novel SYK gene variations and changes in binding sites of miRs in breast cancer patients. Cancer Biomarkers: Section A of Disease Markers 16(3), 319-326.

245. Navara, C. S. (2004) The spleen tyrosine kinase (Syk) in human disease, implications for design of tyrosine kinase inhibitor based therapy. Current Pharmaceutical Design 10(15), 1739-1744.

246. Yuan, Y., Mendez, R., Sahin, A., \& Dai, J. L. (2001) Hypermethylation leads to silencing of the SYK gene in human breast cancer. Cancer Research 61(14), 5558-5561.

247. Coopman, P. J., \& Mueller, S. C. (2006) The Syk tyrosine kinase: A new negative regulator in tumor growth and progression. Cancer Letters 241(2), 159-173.

248. Nourbakhsh, N., Emadi-Baygi, M., Salehi, R., \& Nikpour, P. (2018) Gene expression analysis of two epithelial-mesenchymal transition-related genes: Long noncoding RNA-ATB and SETD8 in gastric cancer tissues. Advanced Biomedical Research 7, 42.

249. Veschi, V., Liu, Z., Voss, T. C., Ozbun, L., Gryder, B., Yan, C., ... Thiele, C. J. (2017) Epigenetic siRNA and chemical screens identify SETD8 inhibition as a therapeutic strategy for p53 activation in high-risk neuroblastoma. Cancer Cell 31(1), 50-63.

250. Fang, J., Feng, Q., Ketel, C. S., Wang, H., Cao, R., Xia, L., ... Zhang, Y. (2002) Purification and functional characterization of SET8, a nucleosomal histone H4-lysine 20specific methyltransferase. Current Biology 12(13), 1086-1099.

251. Shi, X., Kachirskaia, I., Yamaguchi, H., West, L. E., Wen, H., Wang, E. W., ...Gozani, O. (2007) Modulation of p53 function by SET8-mediated methylation at lysine 382. Molecular Cell 27(4), 636-646.

252. Lehmann, U., Streichert, T., Otto, B., Albat, C., Hasemeier, B., Christgen, H.,... Länger, F. (2010) Identification of differentially expressed microRNAs in human male breast cancer. BMC Cancer 10(1), 109.

253. Sun, L. L., Wang, J., Zhao, Z. J., Liu, N., Wang, A. L., Ren, H. Y., ... Mi, X. Y.(2014) Suppressive role of miR-502-5p in breast cancer via downregulation of TRAF2. Oncology Reports 31(5), 2085-2092. 
254. Mykkanen, O. M., Gronholm, M., Ronty, M., Lalowski, M., Salmikangas, P., Suila, H., \& Carpen, O. (2001) Characterization of human palladin, a microfilament-associated protein. Molecular Biology of the Cell 12(10), 3060-3073.

255. Parast, M. M., \& Otey, C. A. (2000) Characterization of palladin, a novel protein localized to stress fibers and cell adhesions. Journal of Cell Biology 150(3), 643-656.

256. Gilam, A., Conde, J., Weissglas-Volkov, D., Oliva, N., Friedman, E., Artzi, N.,\& Shomron, N. (2016) Local microRNA delivery targets Palladin and prevents metastatic breast cancer. Nature Communications 7, 12868.

257. Moazzeni, H., Najafi, A., \& Khani, M. (2017) Identification of direct target genes of miR7, miR-9, miR-96, and miR-182 in the human breast cancer cell lines MCF-7 and MDA-MB231. Molecular and Cellular Probes 34, 45-52.

258. Najm, P., \& El-Sibai, M. (2014) Palladin regulation of the actin structures needed for cancer invasion. Cell Adhesion \& Migration 8(1), 29-35.

259. Zhao, Y. S., Yang, W. C., Xin, H. W., Han, J. X., \& Ma, S. G. (2019) MiR-182-5p knockdown targeting PTEN inhibits cell proliferation and invasion of breast cancer cells. Yonsei Medical Journal 60(2), 148-157.

260. Dorairaj, J.J.; Salzman, D.W.; Wall, D.; Rounds, T.; Preskill, C.; Sullivan, C.A.; Lindner, R.; Curran, C.;Lezon-Geyda, K.; McVeigh, T. et al. (2014) A germline mutation in the BRCA1 30UTR predicts Stage IV breast cancer. BMC Cancer 14, 421.

261. Cao, J.; Luo, C.; Peng, R.; Guo, Q.; Wang, K.; Wang, P.; Ye, H.; Song, C. (2016) MiRNAbinding site functional polymorphisms in DNA repair genes RAD51, RAD52, and XRCC2 and breast cancer risk in Chinese population. Tumour 37,16039-16051

262. Jiang, Y.; Qin, Z.; Hu, Z.; Guan, X.;Wang, Y.; He, Y.; Xue, J.; Liu, X.; Chen, J.; Dai, J. et al. (2013) Genetic variation in a hsa-let-7 binding site in RAD52 is associated with breast cancer susceptibility. Carcinogenesis 34, 689-693.

263. Pongsavee, M.; Yamkamon, V.; Dakeng, S.; P, O.c.; Smith, D.R.; Saunders, G.F.; Patmasiriwat, P. (2009) The BRCA1 30-UTR: 5711+421T/T_5711+1286T/T genotype is a possible breast and ovarian cancer risk factor. Genet. Test. Mol. Biomark. 13, 307-317.

264. Newman, B.; Mu, H.; Butler, L.M.; Millikan, R.C.; Moorman, P.G.; King, M.C. (1998) Frequency of breast cancer attributable to BRCA1 in a population-based series of American women. Jama 279, 915-921.

265. Zheng, H.; Song, F.; Zhang, L.; Yang, D.; Ji, P.; Wang, Y.; Almeida, M.; Calin, G.A.; Hao, X.; Wei, Q. et al. (2011) Genetic variants at the miR-124 binding site on the cytoskeleton- 
organizing IQGAP1 gene confer differential predisposition to breast cancer. Int. J. Oncol. 38, 1153-1161.

266. Brendle, A.; Lei, H.; Brandt, A.; Johansson, R.; Enquist, K.; Henriksson, R.; Hemminki, K.; Lenner, P.; Försti, A. (2008) Polymorphisms in predicted microRNA-binding sites in integrin genes and breast cancer: ITGB4 as prognostic marker. Carcinogenesis 29, 1394-1399. 267. Tchatchou, S.; Jung, A.; Hemminki, K.; Sutter, C.;Wappenschmidt, B.; Bugert, P.;Weber, B.H.; Niederacher, D.; Arnold, N.; Varon-Mateeva, R. et al. (2009) A variant affecting a putative miRNA target site in estrogen receptor (ESR) 1 is associated with breast cancer risk in premenopausal women. Carcinogenesis 30, 59-64.

268. Nicoloso, M.S.; Sun, H.; Spizzo, R.; Kim, H.; Wickramasinghe, P.; Shimizu, M.; Wojcik, S.E.; Ferdin, J.;Kunej, T.; Xiao, L. et al. (2010) Single-nucleotide polymorphisms inside microRNA target sites influence tumor susceptibility. Cancer Res. 70, 2789-2798.

269. Forma, E.; Brzezia `nska, E.; Krze’slak, A.; Chwatko, G.; Józzwiak, P.; Szymczyk, A.; Smolarz, B.;Romanowicz-Makowska, H.; Ró za' nski,W.; Bry's, M. (2013) Association between the c. ${ }^{*} 229 \mathrm{C}>\mathrm{T}$ polymorphism of the topoisomerase II_ binding protein 1 (TopBP1) gene and breast cancer. Mol. Biol. Rep. 40, 3493-3502.

270. Forma, E. TopBP1 in DNA Damage Response. In DNA Repair; Kruman, I., (2011) Ed.; INTECH Open Access Publisher: Rijeka, Croatia V4, pp. 281-304.

271. Rolli, M.; Fransvea, E.; Pilch, J.; Saven, A.; Felding-Habermann, B. (2003) Activated integrin alphavbeta3 cooperates with metalloproteinase MMP-9 in regulating migration of metastatic breast cancer cells. Proc. Natl. Acad.Sci. (USA) 100, 9482-9487.

272. Ren, F.; Tang, R.; Zhang, X.; Madushi,W.M.; Luo, D.; Dang, Y.; Li, Z.;Wei, K.; Chen, G. (2015) Overexpression of MMP Family Members Functions as Prognostic Biomarker for Breast Cancer Patients: A Systematic Review and Meta-Analysis. PLoS ONE 10, e0135544. 273. Pirooz, H.J.; Jafari, N.; Rastegari, M.; Fathi-Roudsari, M.; Tasharrofi, N.; Shokri, G.; Tamadon, M.; Sazegar, H.;Kouhkan, F. (2018) Functional SNP in microRNA-491-5p binding site of MMP9 30-UTR affects cancer susceptibility. J. Cell. Biochem. 119, 5126-5134.

274. Poonam Malhotra $\dagger$, Graham H. Read $\dagger$ and Joanne B. Weidhaas. (2019) Breast Cancer and miR-SNPs: The Importance of miR Germ-Line Genetics. Non-coding RNA 5, 27.

275. Sung, H.; Lee, K.M.; Choi, J.Y.; Han, S.; Lee, J.Y.; Li, L.; Park, S.K.; Yoo, K.Y.; Noh, D.Y.; Ahn, S.H. et al. (2011) Common genetic polymorphisms of microRNA biogenesis pathway genes and risk of breast cancer: A case-control study in Korea. Breast Cancer Res. Treat 130, 939-951. 
276. Jiang, Y.; Chen, J.;Wu, J.; Hu, Z.; Qin, Z.; Liu, X.; Guan, X.;Wang, Y.; Han, J.; Jiang, T. et al. (2013) Evaluation of genetic variants in microRNA biosynthesis genes and risk of breast cancer in Chinese women. Int. J. Cancer 133, 2216-2224.

277. Sung, H.; Jeon, S.; Lee, K.M.; Han, S.; Song, M.; Choi, J.Y.; Park, S.K.; Yoo, K.Y.; Noh, D.Y.; Ahn, S.H. et al. (2012) Common genetic polymorphisms of microRNA biogenesis pathway genes and breast cancer survival. BMC Cancer 12, 195.

278. Leaderer, D.; Hoffman, A.E.; Zheng, T.; Fu, A.;Weidhaas, J.; Paranjape, T.; Zhu, Y. (2011) Genetic and epigenetic association studies suggest a role of microRNA biogenesis gene exportin-5 (XPO5) in breast tumorigenesis. Int. J. Mol. Epidemiol. Genet. 2, 9-18.

279. Ma, H.; Yuan, H.; Yuan, Z.; Yu, C.; Wang, R.; Jiang, Y.; Hu, Z.; Shen, H.; Chen, N. (2012) Genetic Variations in Key MicroRNA Processing Genes and Risk of Head and Neck Cancer: A Case-Control Study in Chinese Population. PLoS ONE 7, e47544.

280. Xu, Y., Liu, L., Liu, J., Zhang, Y., Zhu, J., Chen, J., ... Hu, Z. (2011) A potentially functional polymorphism in the promoter region of $\mathrm{miR}-34 \mathrm{~b} / \mathrm{c}$ is associated with an increased risk for primary hepatocellular carcinoma. International Journal of Cancer 128(2), 412-417. 281. Hassan, F. M. (2019) The association of rs2114358 in the miR-1206 polymorphism to chronic myeloid Leukemia. MicroRNA 8(3), 248-252.

282. Ramesh Singh and Yin-Yuan Mo. Role of microRNAs in breast cancer. (2013) Cancer Biology \& Therapy 14:3, 201-212.

283. Hui-Yi Loh, Brendan P. Norman, Kok-Song Lai, Nik Mohd Afizan Nik Abd. Rahman, Noorjahan Banu Mohamed Alitheen and Mohd Azuraidi Osman. (2019) The Regulatory Role of MicroRNAs in Breast Cancer. Int. J. Mol. Sci. 20, 4940. 


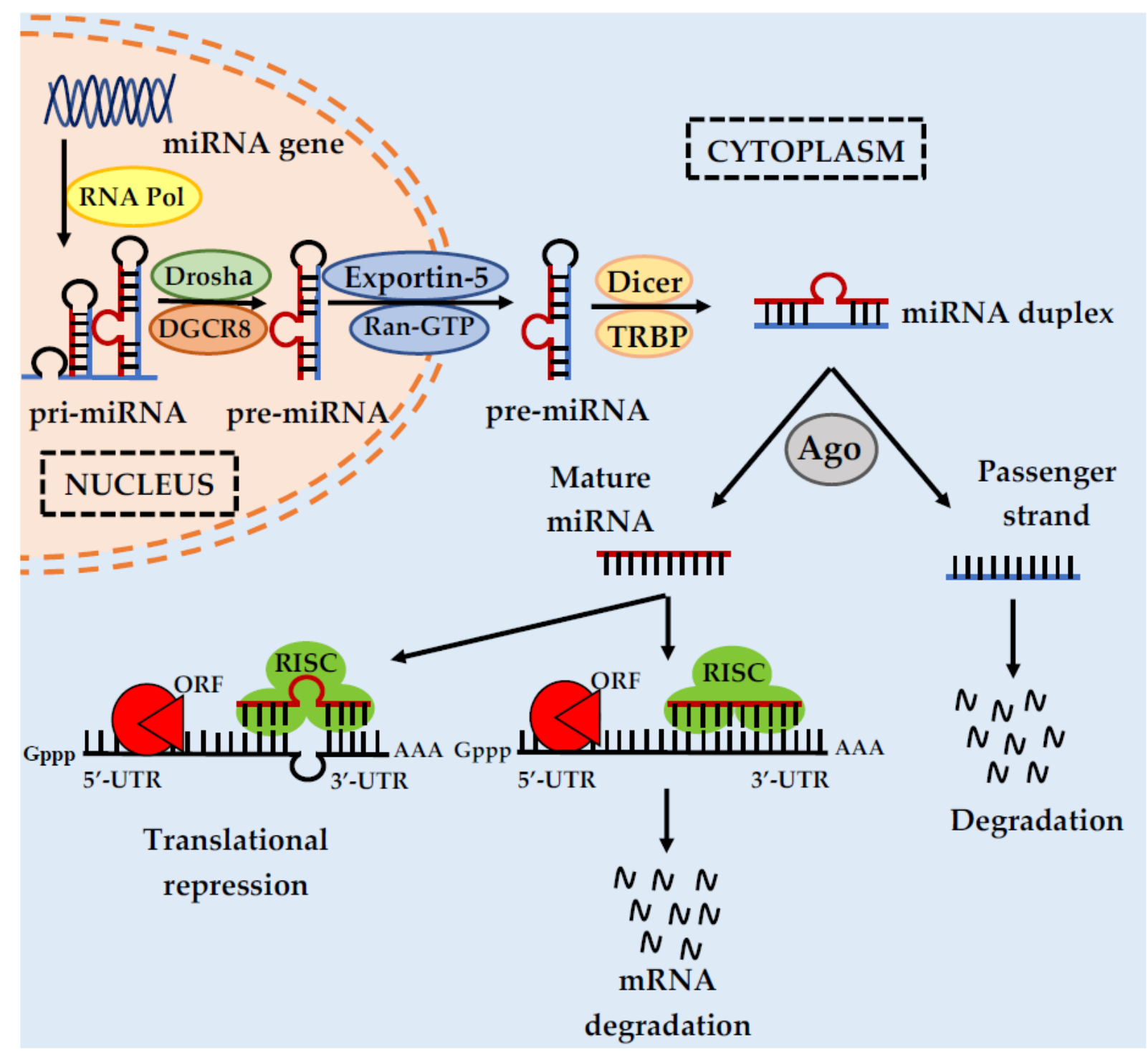

Figure 1: Hui-Yi Loh, Brendan P. Norman, Kok-Song Lai, Nik Mohd Afizan Nik Abd. Rahman, Noorjahan Banu Mohamed Alitheen and Mohd Azuraidi Osman 1, Int. J. Mol. Sci. 2019, $20,4940$. The Regulatory Role of MicroRNAs in Breast Cancer. Reproduced with permission from Bhardwaj, A.; Singh, S.; Singh, A.P. MicroRNA-based cancer therapeutics: Big hope from small RNAs. Mol. Cell Pharmacol. 2010. 